\title{
Mapping the flat glass value-chain: A material flow analysis and energy balance of UK production
}

Rebecca Hartwell ( $\nabla$ rh668@cam.ac.uk)

University of Cambridge https://orcid.org/0000-0002-2261-0745

Graham Coult

Eckersley O'Callaghan

Mauro Overend

Delft University of Technology: Technische Universiteit Delft

\section{Research Article}

Keywords: glass, recycling, energy, circularity, material efficiency, material flow analysis

Posted Date: March 7th, 2022

DOI: https://doi.org/10.21203/rs.3.rs-1401635/v1

License: (c) (i) This work is licensed under a Creative Commons Attribution 4.0 International License.

Read Full License 


\section{Mapping the flat glass value-chain: A material flow analysis and energy balance of UK production}

\section{ABStRACT}

Glass is one of the UK's eight energy-intensive industries. As such, it is under scrutiny to decouple growth in production from greenhouse gas (GHG) emissions. The energy input associated with glass production can be reduced by using recycled glass (cullet) in new glass production, which enables lower furnace operating temperatures and reduces demand for primary raw materials. However, efficient systems for flat glass collection are yet to be established in the UK, resulting in a limited supply of cullet available for the flat glass markets and missed environmental opportunities. This study identifies the existing supply-chain inefficiencies of the UK glass industry in three stages. Firstly, the mass flows of materials within the three main glass sectors: container glass, flat glass and glass wool, are mapped from natural resource through to primary application and subsequent endof-life management based on a reference year of annual production figures. The map is presented in the form of a Sankey diagram which draws attention to several opportunities for increasing resource efficiency; namely in the stark contrast in glass collection rates between the flat and container glass industry. Using the collected data on the annual mass flows of materials in the UK flat glass sub-sector, the energy $(\mathrm{MJ})$ and $\mathrm{GHG}$ emission $\left(\mathrm{CO}_{2}\right.$-eq) saving potential of enhanced end-of-life collection methods are assessed, based on three alternative recovery scenarios. These scenarios consider the use of alternative distributions of recovered flat glass cullet in the three primary glass sub-sectors. The emission savings resulting from each recovery scenario are evaluated, based on the estimated tonnage yield of finished flat glass products. It is shown that together with improved manufacturing yield, the reutilization of end-of-life flat glass as cullet in new production could reduce the annual emissions of the UK flat glass value-chain by up to $18 \%$. Finally we review the existing barriers to recycling different glass types based on acceptability criteria and available take-back infrastructure, and thus find that the advancement of improved recycling rates will rely on establishment of the business opportunity and/or supporting policy for efficient systems of flat glass collection.

Keywords: glass; recycling; energy; circularity; material efficiency; material flow analysis 


\section{INTRODUCTION}

\subsection{Glass Sector}

The glass industry in the United Kingdom and Northern Ireland (UK) accounted for $0.5 \%$ of total UK energy consumption and $0.4-0.6 \%$ of total UK greenhouse gas (GHG) emissions in 2019 (Griffin et al., 2021; Ireson et al., 2019; WSP Parson Brinkerhoff and GL, 2015). It is thus classified as one of the energy-intensive subsectors within the UK industry sector alongside iron and steel (3.6\% of total annual GHGs), chemicals (2.7\%), cement (1.1\%) and aluminium (0.6\%) (Centre for Low Carbon Futures, 2011; Griffin et al., 2016). Glass production can consist of several high-temperature processes. The glass industry has successfully reduced the energy intensity of production in the last 30 years via fuel-switching, advances in furnace technologies, on-site energy efficiency improvements and waste heat recovery processes (British Glass, 2021; Griffin et al., 2016; Hammond and Norman, 2012; IMPEL, 2012; Maria et al., 2013). Additional supply-side efficiency improvements through the use of alternative low-carbon energy sources - such as all-electric melting, hydrogen and biofuels - have been identified as a route for further emission reductions from the energy-intensive industry subsectors. It has been recognized however, that meeting climate targets through supply-side energy efficiency improvements alone will necessitate considerable finance due to the substantial increases in the size of the energy system: in the UK alone, the electricity system would need to quadruple its output (Barrett et al., 2021). It has thus been proposed that there is an urgent need to investigate pathways to reduce gross demand for energy through material efficiency strategies, such as reuse and recycling, to enable a cost effective, timely and de-risked net zero target (Allwood et al., 2013; Barrett et al., 2021).

Container glass for bottles and jars ( 60\%) constitutes the largest glass sub-sector by mass output, followed by flat glass for the architectural and automotive sectors ( 30\%) (BEIS and British Glass, 2017). Glass wool (insulation products) and other applications including domestic glass (decorative glass and household appliances), continuous glass filaments (fibre-reinforced composites and fibre-optics), and pharmaceutical products constitute the remaining mass output ( 10\%) (BEIS and British Glass, 2017). Growth in demand in these sectors has been stimulated by the drive to: retrofit existing inefficient glazing units; find fully-recyclable alternatives to non-recyclable packaging materials; meet new energy-performance standards through durable and non-flammable glass insulation products; and develop glass-fibre reinforced polymers in composite materials for high strength-to-weight ratio applications such as automotive and rotor blades for wind turbines (British Glass, 2021). Each of these products deliver significant performance improvements within the use phase of their application. Still, the full benefits of these performance improvements can only be achieved by concerted efforts to reduce the whole-life 
environmental impact of the glass sector. This will ensure that future growth in UK glass production aligns with the national net zero strategy (HM Government, 2021) and remains competitive internationally.

\subsection{EnVironmental Cost of Glass Manufacturing}

The principal environmental aspects of interest in glass production are resource consumption, the energy efficiency of production, emissions to air and water usage.

\subsubsection{Raw materials}

The main constituents of glass are: silica sand $\left(\mathrm{SiO}_{2}\right)$, soda ash $\left(\mathrm{Na}_{2} \mathrm{CO}_{3}\right)$, calcium carbonate $\left(\mathrm{CaCO}_{3}\right)$ and dolomite $\left(\mathrm{MgCO}_{3}\right)$. The proportions of raw materials used and additional additives vary to a small extent for flatand container-glass products (Gaines et al., 1994; Zier et al., 2021). Fibres for glass wool products use a similar composition of raw materials with a lower proportion of silica sand which is compensated by a greater proportion of calcium carbonate, soda ash and boric oxide (Gaines et al., 1994; Zier et al., 2021). The sourcing and processing of these raw materials requires energy. Soda ash is the most energy-intensive raw material to produce. It is commonly produced via the Solvay (synthetic), Hou (synthetic) or Trona (natural) process. It is estimated that $99 \%$ of soda ash produced in the UK and European Union (EU) is produced via the Solvay process (Belis and Tuokko, 2016; Brunner Mond, 2008). This process requires $6.1-10.0 \mathrm{MJ} / \mathrm{kg}_{\text {soda ash produced }}$ which is equivalent to $0.7-1.0$

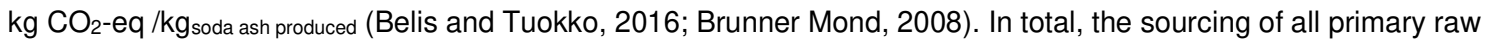
materials for glass production requires $3.8-4.8 \mathrm{MJ} / \mathrm{kg}$ molten glass generating $0.33-0.35 \mathrm{~kg} \mathrm{CO}$-eq $/ \mathrm{kgglass}_{\text {(Guardian }}$ Europe, 2012, 2021; Usbeck et al., 2014; Vitro, 2022). The energy inputs and corresponding emissions associated with raw material sourcing, processing and glass production are illustrated in Figure 1.

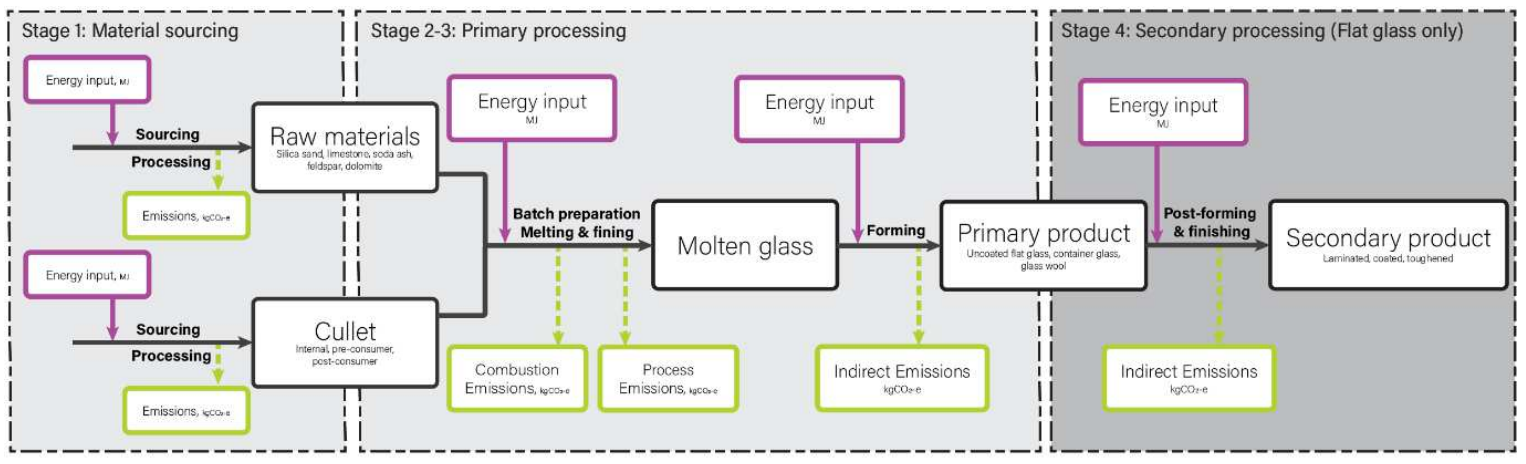

Figure 1: Energy inputs and corresponding emissions associated with glass products including: raw material sourcing and processing (stage 1), primary glass production (stage 2-3) and secondary flat glass processing (stage 4)

\subsubsection{Glass production}

All forms of energy input highlighted in Figure 1 generate associated GHG emissions which in turn correspond to the energy supply and type of raw materials used. Energy is provided directly to the glass production site by the combustion of fossil fuels, by electricity, or by a combination of both sources. The first step in glass production for 
all glass products involves batch preparation where all the raw materials are carefully mixed to the desired composition. Recycled glass, also known as cullet, is also added to the melt. Subsequently the input materials are heated to high temperature $\left(\sim 1500^{\circ} \mathrm{C}\right)$ in the glass furnace to produce molten glass. During this step, GHG emissions arise from the combustion of fuel - typically natural gas - to provide the necessary high temperatures. In addition, carbon dioxide $\left(\mathrm{CO}_{2}\right)$ is emitted as a by-product of the melting process. These $\mathrm{CO}_{2}$ emissions are often referred to as process emissions and arise due to the decomposition of carbonate raw materials. Molten glass is kept at high temperature and transferred to a float glass tank (flat glass), formed (container glass), or blown, spun and merged with binder (glass wool and continuous filament fibre glass). In the forming process of flat glass, rapid temperature changes can occur which induce severe internal stresses within the glass. To prevent these stresses, the glass is passed through an annealing lehr, which involves slowly cooling the glass from $600^{\circ} \mathrm{C}$ to $60^{\circ} \mathrm{C}$. This again requires energy input, either in the form of gas-fired or electric direct heating. Subsequently, flat glass may undergo a series of secondary processing methods - stage 4 on Figure 1 - powered by electricity. These processes can include: the application of coatings, lamination with interlayer products, and/or toughening treatments.

\subsubsection{Use of cullet in new production}

At the end of the glass production line, products pass through an automated quality inspection. At this stage, up to $15 \%$ of flat glass (FG) may be categorised as defective, typically due to unacceptable optical flaws. These glass offcuts are known as internal cullet and can be used in new glass production. The benefits of cullet usage are threefold. Firstly, there is a saving in the energy and emissions associated with the sourcing and processing of the equivalent quantity of raw materials multiplied by a factor of approximately 1.2 . The $20 \%$ difference in total mass input required is due to the decomposition losses incurred during the melting process of carbonate primary raw materials during stage 2 (see Figure 1). Secondly, it allows for the glass furnace to operate at lower temperatures which consequentially reduces the energy consumption of the primary processing stage by $2.5-3.0 \%$ for every $10 \%$ increase in cullet (Beerkens et al., 2011). This, in turn, reduces the associated combustion emissions that are highlighted on Figure 1. Finally, process emissions are reduced, due to the substitution of carbonate raw materials that need to be calcined, with cullet that has already undergone thermal decomposition. Figure 2 shows the relative savings in $\mathrm{CO}_{2}$ emissions from the use of cullet at each stage of glass production. This study will consider the extent to which the primary saving associated with reduced primary raw material usage (stage 1 on Figure 2) will be offset by the transportation and reprocessing costs of "furnace-ready" cullet. 
Stage 1: Material sourcing

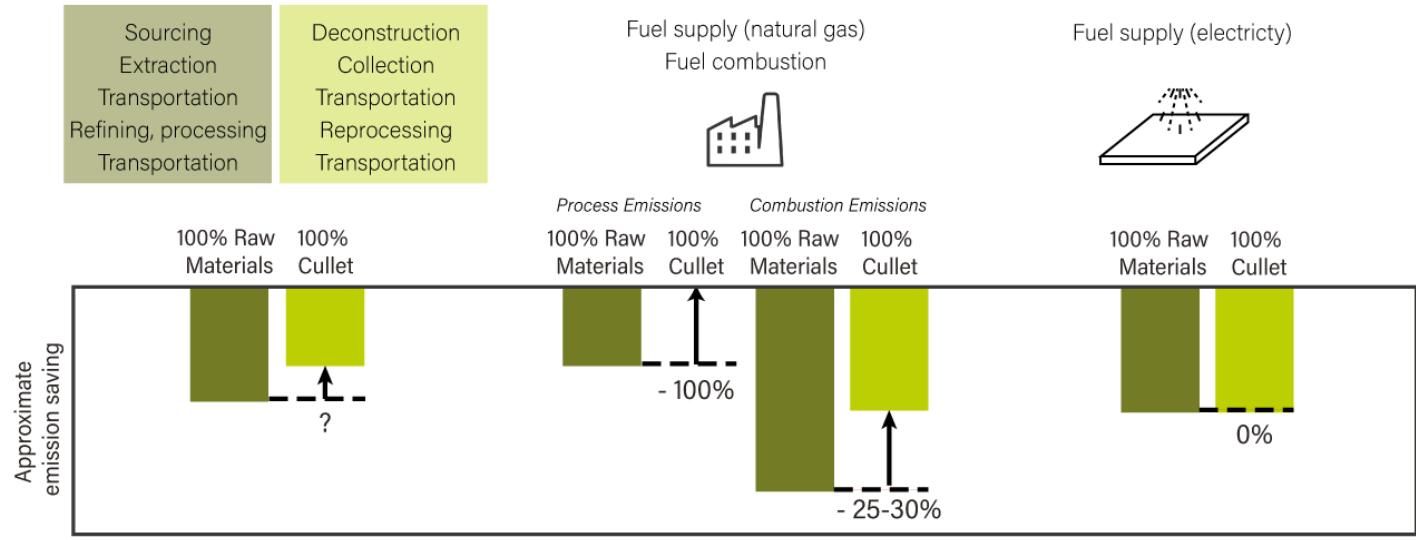

Figure 2: Schematic of emission savings potential from the use of cullet at each stage of flat glass production
Stage 4: Secondary processing

uel supply (electricty)

Raw $100 \%$

100\% Raw $\quad 100 \% \quad 100 \%$ Raw $100 \%$

There are in fact three types of cullet used in glass production. Internal cullet is generated at the glass production facility as a consequence of product changeovers and below-specification glass. Pre-consumer cullet is generated through the downstream manufacturing of products that contain glass; becoming waste before ever reaching the consumer market. An example of pre-consumer cullet is the off-cuts from jumbo sheet glass provided to glass processors, which can then be returned to the glass manufacturer before re-melting. Post-consumer cullet is waste glass arising when a glass product has reached its end-of-life after a period of time in use. The generation of manufacturing waste at the glass production sites (internal cullet) and/or downstream manufacturers (preconsumer cullet) will proportionally reduce the total output of flat glass to final product.

Schmitz et al conducted an in-depth analysis of the direct and indirect energy consumption and $\mathrm{CO}_{2}$ emissions (illustrated as stages 2-3 on Figure 1) of the European glass industry based on EU ETS data for 2005-2007 (Schmitz et al., 2011). The container glass (CG) and glass wool (GW) subsector were found to produce a much lower figure for process emission intensity per tonne $(C G=0.10 \pm 15 \%$ and $G W=0.07 \pm 16 \%)$ than flat glass $(F G=$ $0.19 \pm 17 \%$ ) on average across the then EU25 countries. (Schmitz et al., 2011). It was thus estimated that GW, CG and FG subsectors were typically operating at $55 \%, 45 \%$ and $5 \%$ cullet (internal/pre-/post-consumer) usage, respectively, within the EU25 in 2005-2007.

At present, there is no common international standard or specification for post-consumer cullet. The (JRC European Comission, 2011) developed a guidance document for the end-of-waste criteria for reprocessed cullet based on a comprehensive review of existing literature and contributions from technical experts across the European glass industry. This includes a summary of the minimum quality criteria for "furnace-ready" cullet in terms of maximum permissible levels of typical contamination from metals, organic and inorganic material for the container glass, flat glass and glass wool sub-sectors. Quality requirements for cullet use in flat glass production were found to be much stricter than for container glass and glass wool. For example, impurities from non-ferrous metals in container glass and glass wool production are acceptable if their particle size is less than $0.1 \mathrm{~g}$ and the total amount falls below 20 
$\mathrm{g} /$ tonne $(20 \mathrm{ppm})$. For flat glass, the total proportion of non-ferrous impurities must be lower than $0.5 \mathrm{~g} /$ tonne $(0.5$ ppm). Contamination limits for secondary applications that do not require remelting such as ceramic sanitary ware and fluxing agents for brick manufacture are even less stringent. However, the distribution of recovered cullet to such "open-loop" secondary applications has been found to yield significantly lower environmental benefits (Enviros Consulting Ltd, 2003).

\subsection{Efforts to Decarbonize the UK Glass Industry}

(WSP Parson Brinkerhoff and GL, 2015), (Griffin et al., 2021), and (British Glass, 2021) - the main representative body for the UK glass industry - have published industry roadmaps for the glass sector to achieve carbon neutrality by 2050 in response to the UK's commitment to Net Zero (HM Government, 2021). The key strategies to reduce the emissions associated with glass production by 2050 proposed within these studies include: alternative raw material input to reduce process emissions through increased use of cullet, the use of pre-calcined raw materials and/or alternative raw materials; the use of alternative fuel sources to reduce combustion emissions such as oxyfuel combustion, liquid biofuels, all-electric melting, hybrid furnaces and/or hydrogen and; remediation options such as carbon capture utilization and/or storage (CCU/CCS) - see appendix A1 (British Glass, 2021). Zier et al presented a comprehensive review of the decarbonization options in the German glass sector terms of $\mathrm{CO}_{2}$ reduction potential and economic viability (Zier et al., 2021). They investigated the various existing and future energy sourcing options for powering the glass furnace and concluded that electrical melting and/or hydrogen combustion were the most promising options to drastically reduce combustion emissions.

Whilst combustion emissions may be drastically reduced through fuel-switching, process emissions remain intrinsically related to the raw material composition of glass products. Unless sourced as by-products from other industries, the use of calcined raw materials would merely shift the emission of $\mathrm{CO}_{2}$ emissions to another stage in the glass manufacturing value-chain. Arguably, the process could become more inefficient as a consequence of heating the materials twice. Emission remediation options, such as CCU/CCS technologies, are at early stages of development and have yet to be proven for use on glass furnaces (Anderson and Peters, 2016; Butnar et al., 2020; Griffin et al., 2021; The Royal Society, 2021). Relying on CCU/CCS or the use of calcined raw materials to reduce process emissions is thus likely to fall short in achieving the desired outcome of reducing global GHG emissions in the medium-term.

Increasing the percentage of cullet used would have direct and clear benefits for reducing the process emissions. Simultaneously, it holds the potential to lower the furnace operating temperatures and thus reduce the demand for energy input from alternative fuel supplies. When reporting emission reduction strategies, the glass industry typically refer to the emissions associated with the primary processing of glass, represented as stage 2 on Figure 1. These emissions are often referred to as scope 1 emissions (GHG Protocol Initiative, 2012). Alternative fuel 
sources and combustion methods such as oxyfuel combustion, hydrogen combustion and all-electric melting all have their own energy costs associated with fuel supply. The corresponding emissions associated with purchased electricity and fuel sourcing (scope 2-3) are often referred to as Well-to-Tank (WTT) emissions (GHG Protocol Initiative, 2012). In the wider context of reducing global emissions, it is important to consider the environmental cost of all processes across the glass value-chain. In addition to WTT emissions, it is also essential to consider the environmental trade-offs within the raw material sourcing and processing stage (stage 1 in Figure 1) for primary raw materials compared with cullet. This will enable a transparent and comprehensive evaluation of the use of alternative raw materials and fuel sources as a route to decarbonise the glass sector.

\subsection{End-OF-Life Applications for Glass Products}

Glass as a primary product, prior to any secondary processing methods, can be recycled without loss in quality. The existing end-of-life recovery routes for the three primary UK glass markets are shown on Figure 3.

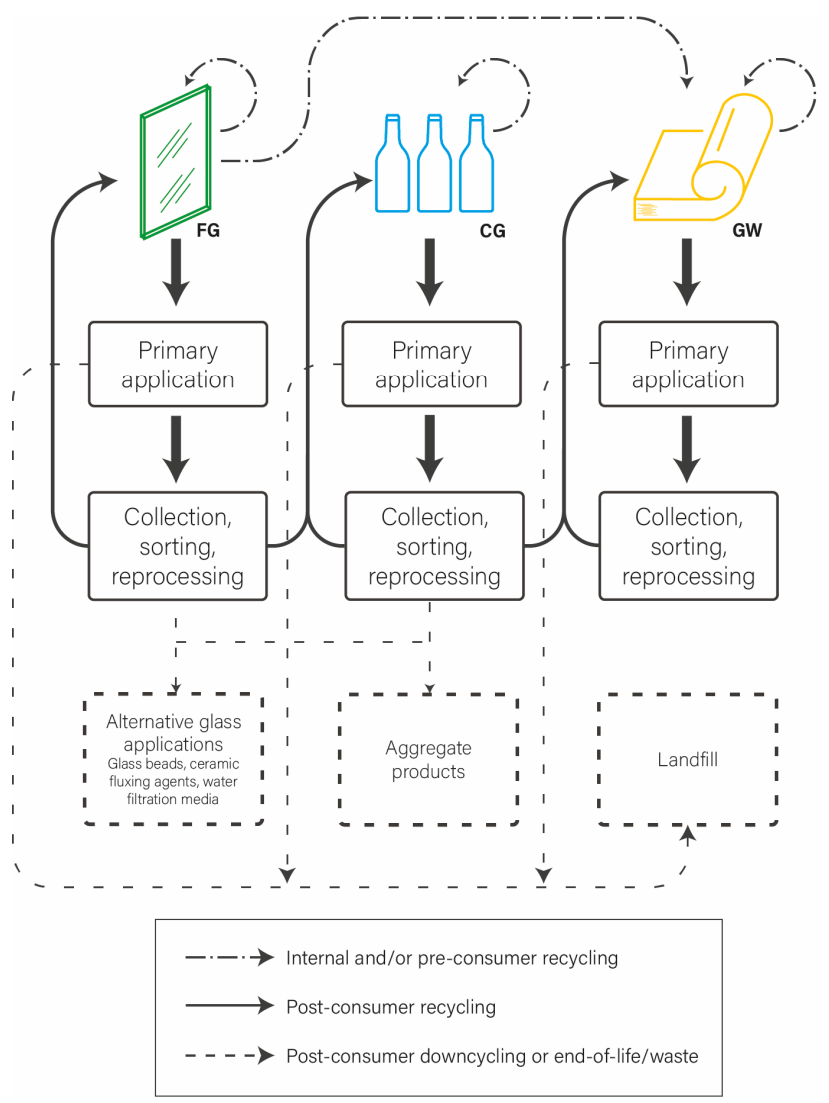

Figure 3: Schematic of existing recovery routes for flat glass (FG), container glass (CG) and glass wool (GW) in the UK

Flat glass (FG) manufacturers typically use $10-25 \%$ of cullet in new glass production. The vast majority of this cullet is internal or pre-consumer cullet: it is estimated that new flat glass production in the UK contains no more than $1 \%$ of post-consumer flat glass. Products incorporating flat glass often incorporate coatings, frits and 
interfaces with other materials such as adhesive polymers and metal parts (DeBrincat and Babic, 2018). The principal barrier for increasing the rates of post-consumer recycling is the effective recovery of flat glass cullet that is free from contaminants, with an acceptable quality, at a reasonable cost. In contrast, the acceptability thresholds for the use of cullet in new flat glass production are very high in order to guarantee compliance with relevant product standards and minimise optical defects in particular (JRC European Comission, 2011).

The container glass (CG) industry has made significant efforts to recover its products beyond their first use to use the collected cullet in new production and consequentially reduce waste to landfill. This is achieved through a wellestablished system of collection through bottle banks or household collection of co-mingled recyclable waste. Collected CG is then separated at a material recovery facility and then sent to a reprocessor where the cullet is sorted and reprocessed to a quality that complies with a customer specification. Quality checks will be performed to ensure that the cullet meets the desired specification which may include checks on: maximum permissible limits on ferrous metals, non-ferrous metals, inorganics and organics; cullet size; moisture content; and cullet colour. The UK achieved a $76.5 \%$ rate of container glass collected for recycling in 2019 , which is approximately equal to the European average (British Glass, 2020; FEVE, 2018). Thus new container glass production contains $~ 50-52 \%$ post-consumer cullet from UK sources (Action et al., 2020; Lee et al., 2019). The percentage of recycled content varies between glass products due to a significant imbalance in the proportions of clear, green and amber glass produced relative to those utilized in the UK (Valpak, 2012).

(Norman, 2013) detailed the drivers and barriers to improving energy efficiency in the energy-intensive sub-sectors within UK industry and highlighted the need to increase information on energy use and motivations to reduce it across the value-chain. (Hartwell et al., 2021) completed a cross-industry review on the barriers and motivations to realising the circular economy in the design of façade systems, including architectural glass. It was found that an improved understanding of the environmental value of reuse and recycling would be a key lever to influencing design decisions that better consider whole-life environmental performance and/or justifying financial investments in effective take-back supply-chains. Several studies have highlighted the challenges of incorporating postconsumer cullet in new FG production and called for better collection and sorting practices (DeBrincat and Babic, 2018; Edgar et al., 2008; Leong and Hurley, 2004; WSP Parson Brinkerhoff and GL, 2015). The opportunities with reference to: the whole glass sector value-chain and influence of secondary processing methods; available cullet in the UK; alternative pathways for recovery; and resulting energy and emission savings within the glass sector, have not yet been evaluated. To this end, this study seeks to evaluate the environmental impact of the use of postconsumer flat glass cullet in new glass production, based on existing resource flows and alternative scenarios for end-of-life management. 


\subsection{Resource Flows for Flat Glass}

It is well-known that there is an increasing demand for cullet from the FG, CG and GW sectors. The availability of 'furnace-ready' cullet is an essential prerequisite for increasing the use of cullet in new glass production. Existing knowledge on the gross availability of UK flat glass cullet and its suitability for secondary applications is limited. Another key factor that remains unclear is the real energy costs and/or savings relating to glass offcuts produced as internal- and/or downstream-manufacturing waste which are later used as cullet in new production. Cullen and Allwood have produced informative maps of global steel and aluminium production, based on mass tonnage figures, from raw materials to end-of-life, thus identifying preventable yield losses and providing suggestions for relevant material efficiency strategies (Cullen et al., 2012; Cullen and Allwood, 2013). Coenraad et al produced a similar map for the flat- and container-glass markets by mass which provides a useful overview of global production figures, but the use of recovered glass across sub-sectors was not considered (Westbroek et al., 2021). Further, the segmentation of the flat glass sector by product type / relevant energy inputs / corresponding emissions was excluded. (Souviron and Khan, 2021) assessed the environmental footprint of the architectural flat glass sector in Belgium, France and the EU. They provide a useful overview of the: tonnage flows of raw materials; energy-mix; energy-; and $\mathrm{CO}_{2}$-intensity with relation to scope-1 emissions in the $\mathrm{FG}$ sector alone over the last 75 years in these regions.

\subsection{Aim OF ThIS Study}

This study examines the emission reduction potential of increased use of cullet and the efficiency of existing and potential future end-of-life recovery routes for flat glass in the UK by:

- mapping the mass flows of materials from nature resources through to primary application and subsequent end-of-life management and secondary use;

- conducting an energy balance of flat glass recovery based on original energy inputs from raw material sourcing through to final product to evaluate the environmental impact of existing and potential future endof-life recovery routes;

- evaluating the impact of two alternative manufacturing yield scenarios to provide a more comprehensive understanding of the real energy costs and/or savings relating to glass offcuts produced as internal- and/or downstream-manufacturing waste and later used as cullet in new production;

- $\quad$ estimating the emission savings across the glass sector from improved collection methods for flat glass based on an estimate for the future availability of flat glass cullet;

- discussing the existing technological, supply-chain, economic, and governmental barriers to increased flat glass recycling in the UK. 


\section{Methodology}

\subsection{ASSEMBLING MASS FIGURES}

Glass production figures and distributions by product type in the UK were collated from a literature review and subsequently inspected alongside annual production output data from (ONS, 2021) covered by the Eurostat ProdCom survey which collects from a sample of approximately 21,500 businesses, covering 240 subsectors of the mining, quarrying, and manufacturing industry sectors. Some product outputs in the ProdCom database are measured in categorical units rather than mass-based which renders them useful only as a guide alongside the other supporting references. The references for the glass production figures sourced for this study are summarised in Table 1. The annual tonnages are denoted relative to end-use i.e. tonnage of new glass production is referred to as "inflow" and tonnage of end-of-life glass generated per annum is denoted as "outflow". Production figures are collated from an extensive literature review and direct communications with the glass value-chain.

Table 1: Data sources for UK glass production and UK glass collection figures

\begin{tabular}{|c|c|c|c|c|}
\hline Product & Inflow sources (Literature) & $\begin{array}{l}\text { Inflow } \\
\text { sources } \\
\text { (ONS, } \\
2021)\end{array}$ & $\begin{array}{l}\text { Product } \\
\text { distribution and } \\
\text { collection routes }\end{array}$ & Outflow sources \\
\hline $\begin{array}{l}\text { Flat glass } \\
\text { (FG) }\end{array}$ & $\begin{array}{l}\text { Flat glass production has } \\
\text { fluctuated between } 750-1100 \\
\text { kt per annum over the last } 25 \\
\text { years. (WRAP, 2008a, 2008b, } \\
\text { 2007) }\end{array}$ & $\begin{array}{l}950 \mathrm{kt} \\
(2019)\end{array}$ & $\begin{array}{l}\text { Private } \\
\text { communications } \\
\text { with reprocessing } \\
\text { facilities and } \\
\text { (Hestin et al., 2016) } \\
\text { (Kellenberger et al., } \\
\text { 2007) }\end{array}$ & $\begin{array}{l}\text { The typical service life of a glazing unit is } 25 \\
\text { years. Based on the production of FG in } \\
1996 \text { production, this would yield an outflow } \\
\text { of } 690 \mathrm{kt} \text { (Kellenberger et al., 2007; Maria et } \\
\text { al., 2013). (WRAP, 2009) estimates an } \\
\text { outflow of } 670-770 \text { kt per annum. (Hestin } \\
\text { et al., 2016) used a top-down method to } \\
\text { estimate glass stock based on the typical } \\
\text { mass of insulated glazing units (IGUs) and } \\
\text { estimated an outgoing flow of } 215 \mathrm{kt} \text { in } 2025 \\
\text { and (Kellenberger et al., 2007) estimated } \\
\text { that IGUs account for } 40-50 \% \text { of the building } \\
\text { market. As a conservative estimate, the } \\
\text { outflow of FG from glazing products in this } \\
\text { study is taken as } 60 \% \text { of FG output in } 2019 \text {. } \\
\text { The typical service life of automotive glazing } \\
\text { is taken as that of an average car } 12 \text { years. } \\
\text { Sales in automotive FG have not } \\
\text { significantly varied in the last } 12 \text { years } \\
\text { therefore the outflows have been taken to be } \\
\text { equivalent to the inflows. }\end{array}$ \\
\hline $\begin{array}{l}\text { Container } \\
\text { glass (CG) }\end{array}$ & $\begin{array}{l}\text { Last recorded figure for } \\
\text { container glass production was } \\
2700 \text { kt in } 2011 \text { with an } \\
\text { estimated average growth of } \\
1 \% \text { per year. (Valpak, 2012) }\end{array}$ & $\begin{array}{l}2900 \mathrm{kt} \\
(2019)\end{array}$ & $\begin{array}{l}\text { (Lee et al., 2019; } \\
\text { Valpak, 2012) }\end{array}$ & $\begin{array}{l}\text { CG is typically used and disposed within at } \\
\text { least one year. Therefore outflows have } \\
\text { been taken to be equivalent to the inflows. }\end{array}$ \\
\hline $\begin{array}{l}\text { Glass wool } \\
(\mathrm{GW})\end{array}$ & $\begin{array}{l}\text { Last recorded figure for glass } \\
\text { wool production was } 228 \mathrm{kt} \text { in } \\
2011 \text {. The last estimated } \\
\text { figure, based on high growth in } \\
\text { the sector, was } 288 \mathrm{kt} \text { in } 2015 \text {. } \\
\text { (WRAP, 2007) }\end{array}$ & $\begin{array}{l}275 \mathrm{kt} \\
(2019)\end{array}$ & $\begin{array}{l}\text { (Insulation, 2020; } \\
\text { Isover, 2021) }\end{array}$ & $\begin{array}{l}\text { The GW market has seen strong growth in } \\
\text { the last } 25 \text { years. As a conservative } \\
\text { estimate, the outflow of glass wool is taken } \\
\text { as } 30 \% \text { of GW output in } 2019 \text {. }\end{array}$ \\
\hline $\begin{array}{l}\text { Other glass } \\
\text { products inc. } \\
\text { glass fibres } \\
\text { for non- } \\
\text { insulating } \\
\text { products }\end{array}$ & $\begin{array}{l}\text { Last recorded figure was in } \\
2008 \text { (WRAP, 2008a). }\end{array}$ & $\begin{array}{l}180 \mathrm{kt} \\
(2009- \\
2019)\end{array}$ & $\begin{array}{l}\text { Assumed to hold } \\
\text { the same collection } \\
\text { ratio container } \\
\text { glass }\end{array}$ & $\begin{array}{l}\text { Typically used and disposed within at least } \\
\text { one year. Therefore outflows have been } \\
\text { taken to be equivalent to the inflows. }\end{array}$ \\
\hline
\end{tabular}


The data collated in Table 1, is plotted in a Sankey diagram (Figure 5) in Python using freely-available Plotly code (Plotly Technologies Ltd., 2015). The nodes shown on the Sankey diagram represent a processing or product stage. The widths of the directed arrows between the nodes are proportional to the mass flows between each processing and/or product stage. The outgoing flows (left-to-right) indicate the demand on primary raw materials; successive distribution of end-use products within their relevant sub-sectors; and subsequent recovery/disposal route beyond first application. The return flows (right-to-left) represent the quantity of material that is recovered and utilized in new production for a second application.

\subsection{Energy Balance of Flat Glass Production to Secondary Applications}

\subsubsection{Primary application}

An energy flow diagram was constructed to draw attention to the associated energy inputs and outputs associated with the production of $1 \mathrm{~kg}$ of flat glass output in a primary application (architectural glazing or automotive). The energy associated with $1 \mathrm{~kg}$ of flat glass output is calculated based on a distribution of primary FG products. The distribution of primary FG products was estimated based on typical manufacturing outputs in the EU (Kellenberger et al., 2007; Maria et al., 2013) and is illustrated on Figure 4.

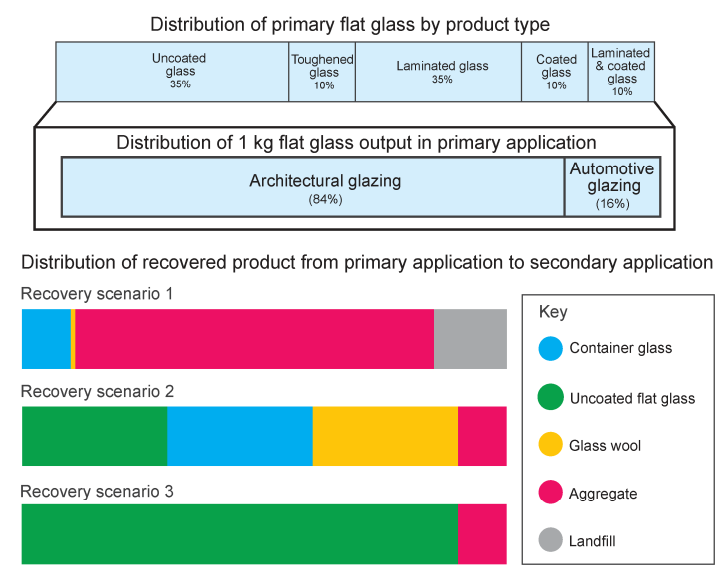

Figure 4: Distribution of $1 \mathrm{~kg}$ flat glass product by primary application and subsequent distribution of recovered product from primary application to secondary application in the three alternative recovery scenarios

\subsubsection{Secondary application recovery scenarios}

The three alternative recovery scenarios illustrated in Figure 4 were constructed to compare and evaluate the effects of redirecting end-of-life flat glass to new products in varying proportions including: uncoated flat glass (UFG); container glass (CG); glass wool (GW) -; lower-grade aggregate products (AGG); and/or landfill (LA). The proportional distribution of recovered product to secondary application are illustrated in Figure 4 and detailed in Table 2. Scenario 1 is representative of the existing end-of-life flows of flat glass. Scenarios 2 and 3 were constructed to represent the instance where improvements to existing collection infrastructures allow higher 
proportions of waste glass to be reprocessed and utilized in new glass products. The energy use and savings associated with the use of end-of-life flat glass (i.e. post-consumer flat glass cullet) into the three alternative recovery scenarios was then evaluated.

Table 2: Product destination for $1 \mathrm{~kg}$ of flat glass output collected at end-of-life in the three constructed recovery scenarios

\begin{tabular}{|c|c|c|c|c|c|}
\hline Recovered Factor & $\begin{array}{c}\text { Uncoated flat } \\
\text { glass (UFG) }\end{array}$ & $\begin{array}{c}\text { Container glass } \\
\text { (CG) }\end{array}$ & $\begin{array}{c}\text { Glass wool } \\
\text { (GW) }\end{array}$ & $\begin{array}{c}\text { Aggregate } \\
\text { (AGG) }\end{array}$ & Landfill (LA) \\
\hline Scenario 1 & $0 \%$ & $10 \%$ & $1 \%$ & $74 \%$ & $15 \%$ \\
\hline Scenario 2 & $30 \%$ & $30 \%$ & $30 \%$ & $10 \%$ & $0 \%$ \\
\hline Scenario 3 & $90 \%$ & $0 \%$ & $0 \%$ & $10 \%$ & $0 \%$ \\
\hline
\end{tabular}

\subsubsection{Energy Inputs}

The energy inputs and corresponding emissions associated with stages 1 and 4 - illustrated on Figure 1 - were collated from existing environmental product declarations and the Ecolnvent database (Wernet et al., 2016). Data for the production stages 2-3 was collected from (Schmitz et al., 2011) who conducted an in-depth analysis of the energy consumption and $\mathrm{CO}_{2}$ emissions of 450 European glass installations based on EU ETS data for the period 2005-2007. UK-government fuel source specific conversion factors (BEIS, 2020) were applied to account for the energy associated with fuel supply (i.e. to convert the total delivered energy into primary energy - see appendix A2). Existing literature provides data for the embodied energy and embodied carbon of glass products with a range of recycled contents $(\mathrm{RC})$. Where data for $0 \% \mathrm{RC}$ was not found, the embodied energy and embodied carbon figures in Table 3 have been scaled based on the equivalent energy and emission savings (Beerkens et al., 2011) that arise in stage 1 and 2 from using cullet in new production for UFG, CG and GW.

Table 3: Distribution of energy input and equivalent embodied carbon for the major processing steps of flat glass, container glass, glass wool and aggregate products

\begin{tabular}{|c|c|c|c|c|c|}
\hline & & FG (0\% RC) & CG (0\% RC) & GW (0\% RC) & AGG (0\% RC) \\
\hline \multirow{4}{*}{$\begin{array}{l}\text { Embodied } \\
\text { energy } \\
\text { distribution } \\
\text { between } \\
\text { product } \\
\text { stages }\end{array}$} & $\begin{array}{l}\text { 1: Raw material sourcing \& } \\
\text { transportation }\end{array}$ & $\begin{array}{l}24 \% \text { (Guardian } \\
\text { Europe, 2012) }\end{array}$ & $\begin{array}{l}28 \% \text { (Guardian } \\
\text { Europe, 2012) }\end{array}$ & $\begin{array}{l}\text { 16\% (Guardian } \\
\text { Europe, 2012) }\end{array}$ & $\mathrm{N} / \mathrm{A}$ \\
\hline & 2: Glass melting & $\begin{array}{l}61 \% \text { (Schmitz } \\
\text { et al., 2011) }\end{array}$ & $\begin{array}{l}57 \% \text { (Schmitz } \\
\text { et al., 2011) }\end{array}$ & $\begin{array}{l}39 \% \text { (Schmitz } \\
\text { et al., 2011) }\end{array}$ & $\mathrm{N} / \mathrm{A}$ \\
\hline & $\begin{array}{l}\text { 3: Molten glass to primary } \\
\text { product }\end{array}$ & $\begin{array}{l}15 \% \text { (Schmitz } \\
\text { et al., 2011) }\end{array}$ & $\begin{array}{l}15 \% \text { (Schmitz } \\
\text { et al., 2011) }\end{array}$ & $\begin{array}{l}45 \% \text { (Schmitz } \\
\text { et al., 2011) }\end{array}$ & $\mathrm{N} / \mathrm{A}$ \\
\hline & $\begin{array}{l}\text { 4: Additional processing i.e. } \\
\text { Primary product to secondary } \\
\text { product }\end{array}$ & $\begin{array}{c}\text { COA }=+10 \% \\
\text { (Guardian } \\
\text { Europe, 2021) } \\
\text { LAM = +49\% } \\
\text { (Guardian } \\
\text { Europe, 2021) } \\
\text { TOU = +49\% } \\
\text { (Guardian } \\
\text { Europe, 2012) }\end{array}$ & $\mathrm{N} / \mathrm{A}$ & $\mathrm{N} / \mathrm{A}$ & $\mathrm{N} / \mathrm{A}$ \\
\hline \multicolumn{2}{|c|}{$\begin{array}{l}\text { Total embodied energy: Stages } 1-3 \\
\text { (MJ/kg }\end{array}$} & 16.9 & 14.3 & 25.2 & $\begin{array}{l}0.083 \\
\text { (Hammond and } \\
\text { Jones, 2011) }\end{array}$ \\
\hline \multicolumn{2}{|c|}{$\begin{array}{l}\text { Total energy saving potential }\left(\mathrm{MJ} / \mathrm{kg}_{\text {secondary }}\right. \\
\text { app) }\end{array}$} & 4.5 & 3.8 & 4.4 & 0.083 \\
\hline \multicolumn{2}{|c|}{$\begin{array}{l}\text { Total embodied carbon: Stages } 1-3\left(\mathrm{~kg} \mathrm{CO}_{2^{-}}\right. \\
\text {eq/ kg output })\end{array}$} & 1.29 & 1.13 & 1.69 & $\begin{array}{l}0.0052 \\
\text { (Hammond and } \\
\text { Jones, 2011) }\end{array}$ \\
\hline
\end{tabular}


The raw material composition for FG and CG is similar. For GW, the composition is slightly different (Kellenberger et al., 2007; Zier et al., 2021). For the purpose of this study, the energy associated with raw material sourcing and transportation for each glass product has been taken to be equivalent at $4.05 \mathrm{MJ} / \mathrm{kg}_{\text {glass produced }}$ and $0.32 \mathrm{kgCO}_{2}$ eq / kgglass. These figures are taken from an environmental product declaration which declared 0\% RC (Guardian Europe, 2012). An interim reprocessing step is required to produce cullet of a quality acceptable for new UFG, CG and GW products. This necessitates an additional energy input and equivalent non-recoverable energy loss. Embodied energy and carbon figures for the sourcing of cullet were taken from Beerkens and the Ecolnvent database (Beerkens et al., 2011; Wernet et al., 2016). The embodied energy figure aligns well with the energy associated with the equivalent output of cullet treated at a material recovery facility, where similar processing activities take place (Denison, 1996). An estimation for the transportation of cullet from point of use back to reprocessor or aggregates market was taken as $800 \mathrm{~km}$ and $100 \mathrm{~km}$ respectively, based on the locations of existing manufacturing and reprocessing sites in the UK. Equivalent embodied energy and embodied carbon figures for transportation were calculated based on UK greenhouse gas reporting figures (GOV.UK, 2021). The use of glass in aggregate production does not require a reprocessing step. The relevant calculations for the energy inputs associated with each stage of production are detailed in appendix A2.

Table 3 highlights the difference in energy intensity between uncoated flat glass products and glass wool products. The production of the final glass wool product is more energy-intensive due to the additional fiberizing and curing process required for glass wool products (IMPEL, 2012; Maria et al., 2013). Secondary processes can significantly increase the embodied energy of uncoated flat glass. Coating, lamination and toughening processes have been found to add an additional energy input equivalent to $10 \%, 49 \%$ and $49 \%$ of the embodied energy of uncoated flat glass, respectively (Guardian Europe, 2021, 2012).

\subsubsection{Recoverable Energy}

Energy and emission savings from the use of cullet in new flat glass production arise from the raw material sourcing and glass melting stages. Based on the figures introduced in Table 3 and further detailed in appendix A3, the replacement of $100 \%$ primary raw materials with $100 \%$ post-consumer cullet would yield a total energy saving of $27 \%$ and total emissions saving of $41 \%$ from raw material sourcing through to production into final uncoated flat glass product. These values are taken as the maximum energy available for recovery, MRE, and maximum emission saving potential, MESP. All other energy inputs, including those required to deliver additional processing methods for flat glass production such as coating, laminating, toughening and fabrication into a glazing and/or automotive unit, are evaluated as energy losses that are non-recoverable through recycling. 
After primary use within architectural glazing or automotive product, glass can be transferred to landfill or one of four secondary applications: new uncoated flat glass (FG), container glass (CG), glass wool (GW) or aggregate (AGG). In the case of landfill disposal, $0 \%$ of the MRE is recovered. For the secondary applications, energy can be recovered to various degrees, depending on the equivalent recovered energy, $R E$, achieved from the use of cullet within that secondary application.

\subsubsection{Production Yields}

The production yield represents the percentage of non-defective glass that is passed through to the next stage of glass production. The five scenarios constructed in this study will evaluate two potential yield rates which are presented in Table 4. Scenarios 1A, 2A and $3 \mathrm{~A}$ consider a yield that is representative of current practice for flat glass manufacturing based on estimates from communications with glass manufacturers. Scenarios $1 \mathrm{~B}, 2 \mathrm{~B}$ and 3B take a more aspirational estimate for yield rates.

Table 4: Destination of yields and yield losses for each processing step of flat glass production

\begin{tabular}{|c|c|c|c|c|}
\hline \multirow{2}{*}{ Source } & \multicolumn{2}{|c|}{ Target } & Conservative & $\begin{array}{c}\text { Aspirational } \\
\text { Yield (Yield B) }\end{array}$ \\
\cline { 2 - 5 } & Product (Yield) & Return (Yield Loss) & Yield A) & 0.95 \\
\hline Uncoated & $\begin{array}{c}\text { Toughened / Coated / Laminated / } \\
\text { Architectural glazing }\end{array}$ & Uncoated & 0.85 & 0.95 \\
\hline Toughened & Glazing fabricator / Automotive & Uncoated & 0.90 & 0.95 \\
\hline Coated & Laminated / Glazing fabricator & Uncoated & 0.90 & 0.95 \\
\hline Laminated & Glazing fabricator / Automotive & Uncoated & 0.90 & 0.95 \\
\hline Glazing fabricator & Architectural glazing & Uncoated & 0.90 & 0.90 \\
\hline
\end{tabular}

\subsubsection{Energy Flows from Primary to Secondary Application}

The corresponding energy flows, based on the mass distribution of glass product from raw material through to primary and subsequent secondary application, were plotted on Sankey diagrams (Figure 6 and 7) to provide a visualisation of the associated energy losses associated with production, and equivalent savings that arise from recycling cullet after its primary application. From this, it is possible to evaluate the: primary energy losses from uncoated flat glass production and subsequent processing methods; secondary energy losses from producing secondary application products; and total energy recovered (TRE) and total unrecovered energy (TNRE). A summary of the calculations used to evaluate these factors can be found in appendix A3.

\subsection{Energy and Emissions Savings Potential}

The flat glass market has grown steadily in the last 20 years. An outflow of $600 \mathrm{kt}$ and $200 \mathrm{kt}$ of flat glass in 2021 (the reference year for analysis) have been taken as a high- and low-end estimate based on annual rates of production in the year 1996 and a 25-year lifetime of a glazing unit and steady growth in the automotive glass market (Hestin et al., 2016; Kellenberger et al., 2007; Maria et al., 2013). These two figures have been used to 
provide an indicator for the equivalent energy and emission reduction potential that could be achieved by incorporating post-consumer flat glass in the production of new glass products.

\section{Results}

\subsection{Map of UK Glass Production Flows and Related $\mathrm{CO}_{2}$ Emissions}

The production of glass consumes significant quantities of natural resources. The mass flows of glass production from natural resources through to primary application and recovery into secondary application are shown in Figure 5.

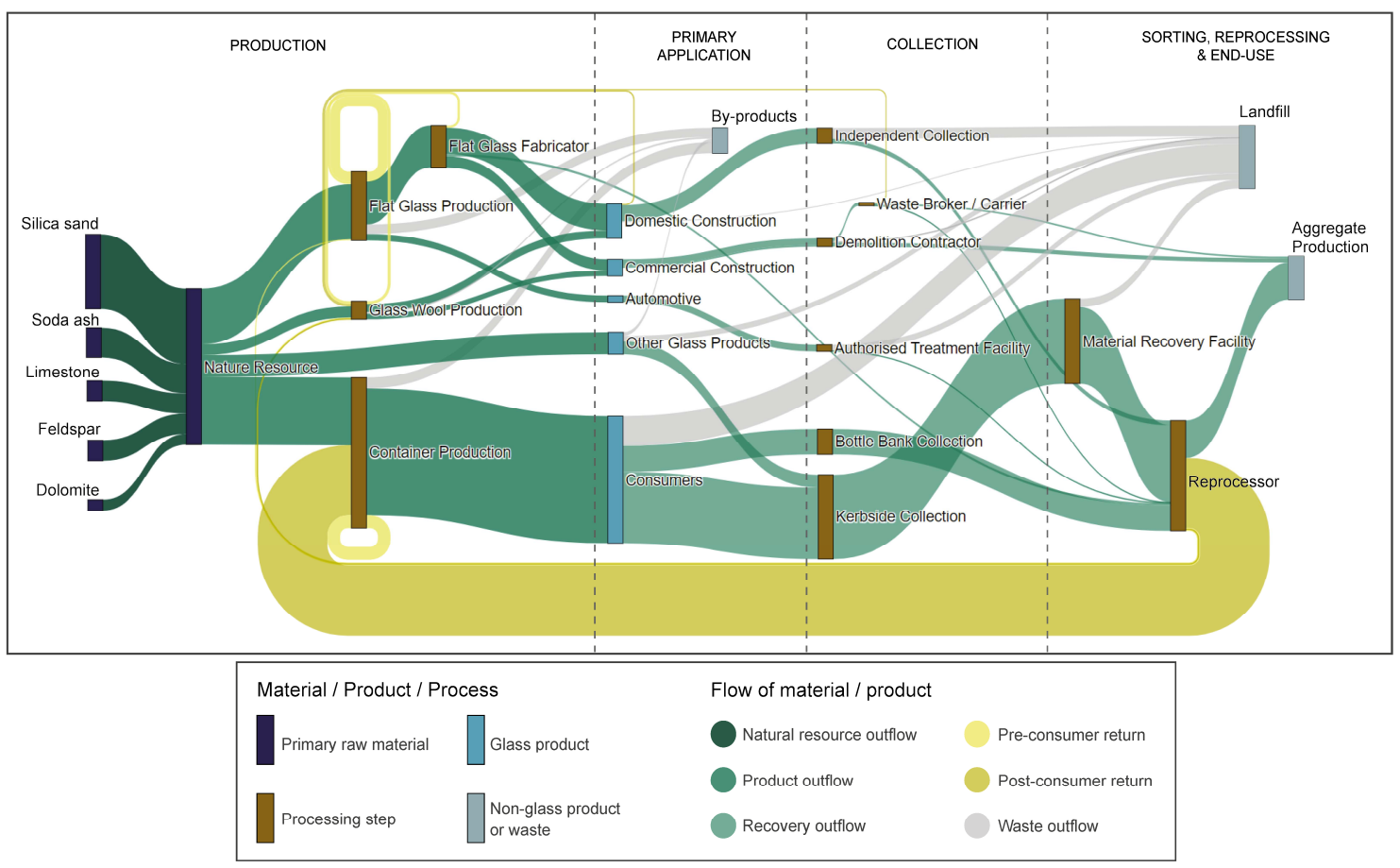

Figure 5: Sankey diagram representative of annual production from the UK glass industry based on existing collection practices

The mass flows plotted on Figure 5 are based on the incoming and outgoing resource flows associated with the total output of finished product within each glass market (flat glass, container glass, glass wool and other glass products) in 2019. The total tonnage output of finished product in each market is detailed in Table 5. 
Table 5: Total tonnage and $\mathrm{CO}_{2}$ emissions associated with each glass sub-sector from raw material to primary application

\begin{tabular}{|c|c|c|c|c|}
\hline & $\begin{array}{l}\text { Total tonnage } \\
\text { produced (kt) }\end{array}$ & $\begin{array}{c}\% \text { RC: Internal \& } \\
\text { Pre-consumer / } \\
\text { Post-consumer }\end{array}$ & $\begin{array}{c}\mathrm{CO}_{2} \text {-eq emissions }{ }^{\star} \text { : } \\
\text { Total per annum } \\
\text { (ktCO }-\mathrm{eq}) / \text { Per unit } \\
\text { output }\left(\mathrm{kgCO} \mathrm{CO}_{2} \text {-eq/kg) }\right.\end{array}$ & $\begin{array}{l}\text { Process Emissions: } \\
\text { Total per annum }\left(\mathrm{ktCO}_{2^{-}}\right. \\
\text {eq) / as } \% \text { of total } \\
\text { annual emissions }\end{array}$ \\
\hline Flat Glass (FG) & 950 & $32 \% /-$ & $1,672^{* *} / 1.76$ & $201 / 12.0 \%$ \\
\hline Container Glass (CG) & 2,700 & $10 \% / 55 \%$ & $2,435 / 0.90$ & $233 / 9.6 \%$ \\
\hline Glass Wool (GW) & 288 & $\begin{array}{c}22 \%(\mathrm{GW}), 8 \%(\mathrm{FG}) \\
/ 25 \%\end{array}$ & $543 / 1.88$ & $37 / 6.8 \%$ \\
\hline Other glass products & 395 & $10 \% / 0 \%$ & $475 / 1.20$ & $76 / 16.0 \%$ \\
\hline Total & 4,483 & - & $5,140 / 1.19$ & $547 / 10.6 \%$ \\
\hline
\end{tabular}

*includes emissions associated with raw material extraction, sourcing and transportation

**includes emissions associated with additional secondary processes for flat glass products

Due to the nature of the raw material composition, each glass product produces $\mathrm{CO}_{2}$ emissions via the thermal decomposition of carbonate raw materials. The percentage of waste by-product in the form of $\mathrm{CO}_{2}$ emissions, also referred to as process emissions in Table 5, is proportional to the post-consumer recycled content of the specific glass product.

\subsection{ENERGY BALANCE OF FLAT GLASS PRODUCTION}

Figure 6 and 7 were plotted to provide a visualisation of the energy balance of recovery scenarios 1 and 2 based on the same conservative production yield $(\mathrm{A})$ detailed in Table 4.

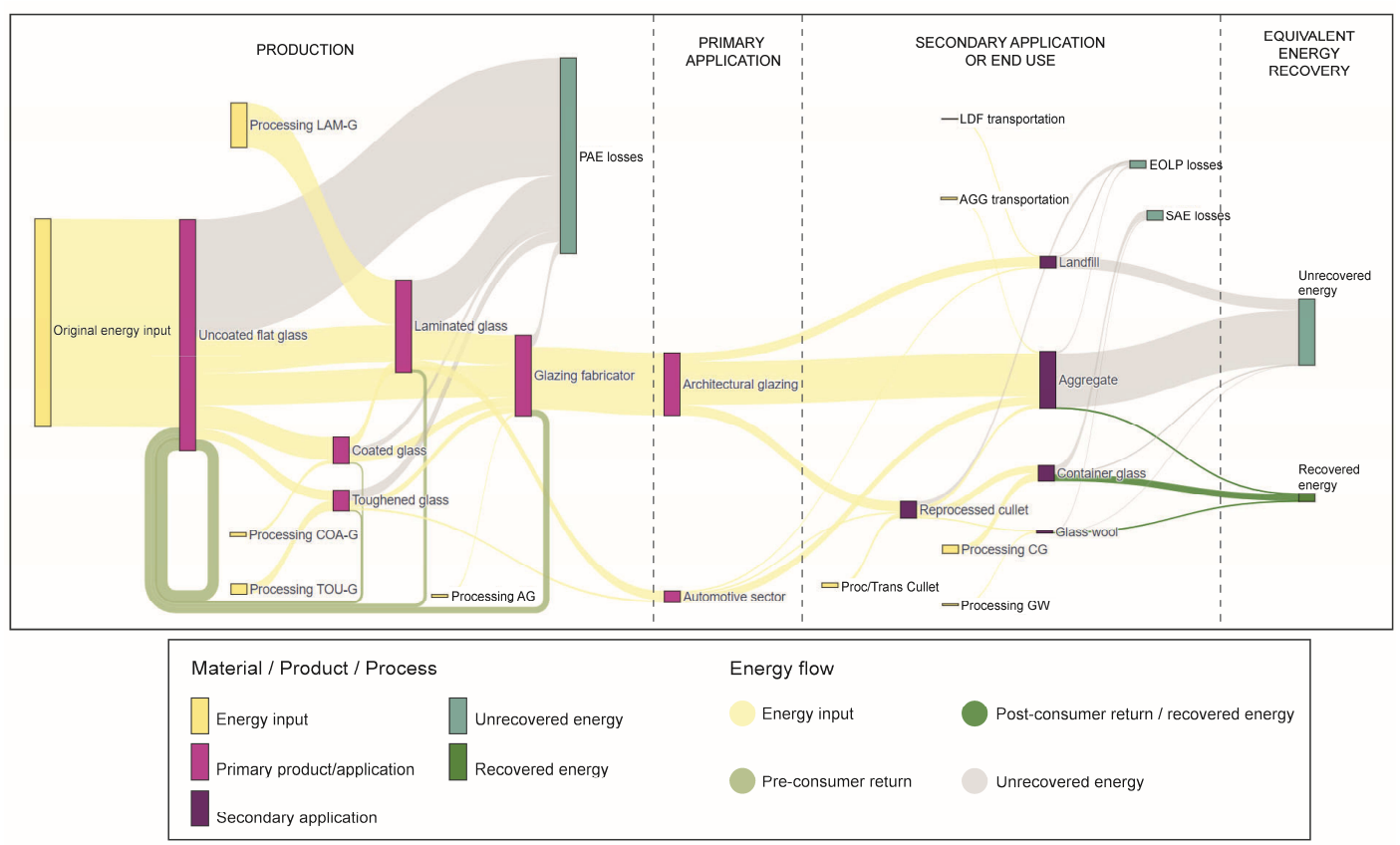

Figure 6: Energy balance of $1 \mathrm{~kg}$ of glass output in scenario 1, based on conservative yield (A) 


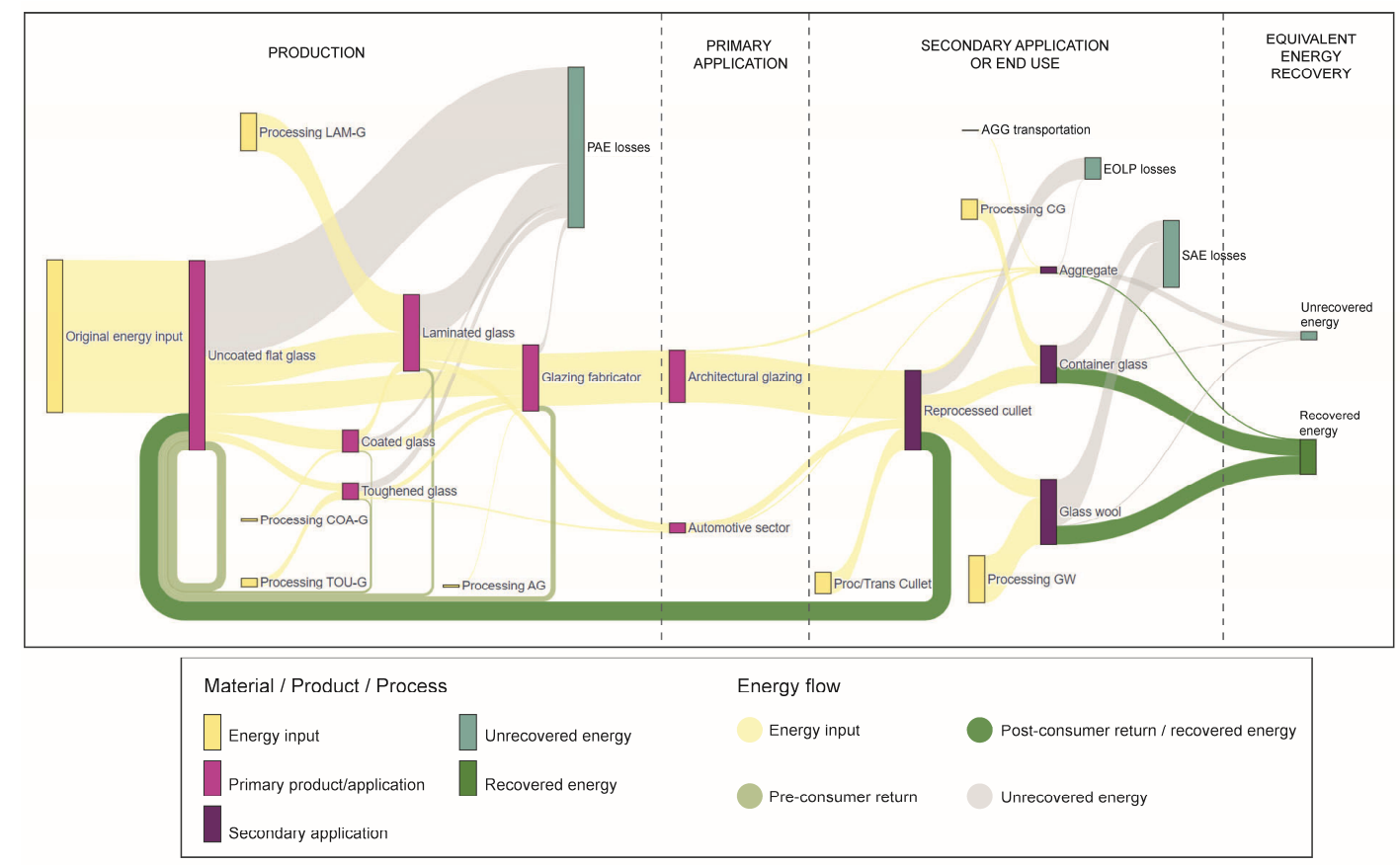

Figure 7: Energy balance of $1 \mathrm{~kg}$ of glass output in scenario 2, based on conservative yield (A)

Table 6 details the energy inputs, associated energy losses, recovered energy (RE) and non-recovered energy (NRE) for the five scenarios presented introduced in section 2.2.

Table 6: Energy input and equivalent recoverable and non-recoverable flows of energy for $1 \mathrm{~kg}$ of primary product with reference to the 5 pre-constructed scenarios

\begin{tabular}{|c|c|c|c|c|c|c|c|}
\hline & & & \multicolumn{2}{|c|}{ Conservative Yield $(A)$} & \multicolumn{3}{|c|}{ Aspirational Yield (B) } \\
\hline & & & $\begin{array}{c}\text { Scenario } \\
1 A\end{array}$ & $\begin{array}{l}\text { Scenario } \\
2 A\end{array}$ & $\begin{array}{l}\text { Scenario } \\
1 B\end{array}$ & $\begin{array}{l}\text { Scenario } \\
2 B\end{array}$ & $\begin{array}{c}\text { Scenario } \\
3 B\end{array}$ \\
\hline \multicolumn{3}{|c|}{ Primary product output } & $1 \mathrm{~kg}$ & $1 \mathrm{~kg}$ & $1 \mathrm{~kg}$ & $1 \mathrm{~kg}$ & $1 \mathrm{~kg}$ \\
\hline \multicolumn{3}{|c|}{ Ratio of Architectural Glazing : Automotive Glazing } & $0.84: 0.16$ & $0.84: 0.16$ & $0.84: 0.16$ & $0.84: 0.16$ & $0.84: 0.16$ \\
\hline \multirow{5}{*}{$\begin{array}{l}\text { Primary } \\
\text { energy input, } \\
\text { MJ }\end{array}$} & \multirow{3}{*}{$\begin{array}{l}\text { Uncoated flat } \\
\text { glass for } 1 \text { unit } \\
\text { of primary } \\
\text { application } \\
\text { output }\end{array}$} & Total & 19.88 & 19.88 & 18.13 & 18.13 & 18.13 \\
\hline & & $\begin{array}{l}\text { From post-consumer } \\
\text { cullet }\end{array}$ & 0.00 & 2.14 & 0.00 & 2.14 & 6.42 \\
\hline & & From new resource & 19.88 & 17.74 & 18.13 & 15.99 & 11.71 \\
\hline & \multicolumn{2}{|c|}{ Secondary processing } & 5.99 & 5.99 & 5.56 & 5.56 & 5.56 \\
\hline & \multicolumn{2}{|c|}{ Total to produce $1 \mathrm{~kg}$ primary product } & 25.86 & 25.86 & 23.69 & 23.69 & 23.69 \\
\hline \multirow{3}{*}{$\begin{array}{l}\text { Primary } \\
\text { application } \\
\text { energy (PAE) } \\
\text { losses }\end{array}$} & \multicolumn{2}{|c|}{$\begin{array}{l}\text { Uncoated flat glass production, MJ } \\
\text { (As \% of total input) }\end{array}$} & $\begin{array}{c}9.73 \\
(37.6 \%)\end{array}$ & $\begin{array}{c}9.73 \\
(37.65 \%)\end{array}$ & $\begin{array}{c}9.73 \\
(41.08 \%)\end{array}$ & $\begin{array}{c}9.73 \\
(41.08 \%)\end{array}$ & $\begin{array}{c}9.73 \\
(41.08 \%)\end{array}$ \\
\hline & \multicolumn{2}{|c|}{$\begin{array}{l}\text { Primary flat glass processing, MJ } \\
\text { (As \% of total input) }\end{array}$} & $\begin{array}{c}5.99 \\
(23.2 \%)\end{array}$ & $\begin{array}{c}5.99 \\
(23.2 \%)\end{array}$ & $\begin{array}{c}5.56 \\
(23.5 \%)\end{array}$ & $\begin{array}{c}5.56 \\
(23.5 \%)\end{array}$ & $\begin{array}{c}5.56 \\
(23.5 \%)\end{array}$ \\
\hline & \multicolumn{2}{|c|}{$\begin{array}{l}\text { Yield losses, MJ } \\
\text { (As \% of total input) }\end{array}$} & $\begin{array}{c}3.01 \\
(11.6 \%)\end{array}$ & $\begin{array}{c}3.01 \\
(11.6 \%)\end{array}$ & $\begin{array}{c}1.26 \\
(5.3 \%)\end{array}$ & $\begin{array}{c}1.26 \\
(5.3 \%)\end{array}$ & $\begin{array}{c}1.26 \\
(5.3 \%)\end{array}$ \\
\hline \multicolumn{3}{|c|}{$\begin{array}{l}\text { Energy available for recovery, } M J \\
\text { (As \% of total input) }\end{array}$} & $\begin{array}{c}7.13 \\
(27.6 \%)\end{array}$ & $\begin{array}{c}7.13 \\
(27.6 \%)\end{array}$ & $\begin{array}{c}7.13 \\
(30.1 \%)\end{array}$ & $\begin{array}{c}7.13 \\
(30.1 \%)\end{array}$ & $\begin{array}{c}7.13 \\
(30.1 \%)\end{array}$ \\
\hline \multirow{3}{*}{$\begin{array}{l}\text { Energy } \\
\text { balance, MJ } \\
\text { (\% energy } \\
\text { available for } \\
\text { recovery / \% } \\
\text { total energy } \\
\text { input) }\end{array}$} & \multirow[t]{2}{*}{$\begin{array}{l}\text { Unrecovered } \\
\text { energy }\end{array}$} & $\begin{array}{l}\text { (due to reprocessing } \\
\text { and transportation } \\
\text { energy input) }\end{array}$ & $\begin{array}{c}0.69 \\
(9.6 \% / \\
2.6 \%)\end{array}$ & $\begin{array}{c}2.54 \\
(35.6 \% / \\
9.8 \%)\end{array}$ & $\begin{array}{c}0.69 \\
(9.6 \% / \\
2.9 \%)\end{array}$ & $\begin{array}{c}2.54 \\
(35.6 \% / \\
10.7 \%)\end{array}$ & $\begin{array}{c}2.54 \\
(35.6 \% / \\
10.7 \%)\end{array}$ \\
\hline & & $\begin{array}{l}\text { (due to secondary } \\
\text { application) }\end{array}$ & $\begin{array}{c}6.35 \\
(89.1 \% / \\
24.6 \%)\end{array}$ & $\begin{array}{c}0.93 \\
(13.1 \% / \\
3.6 \%)\end{array}$ & $\begin{array}{c}6.35 \\
(89.1 \% / \\
26.8 \%)\end{array}$ & $\begin{array}{c}0.93 \\
(13.1 \% / \\
3.9 \%)\end{array}$ & $\begin{array}{c}0.71 \\
(9.9 \% / \\
3.0 \%)\end{array}$ \\
\hline & $\begin{array}{l}\text { Net recovered } \\
\text { energy }\end{array}$ & $\begin{array}{l}\text { (through secondary } \\
\text { application) }\end{array}$ & $\begin{array}{c}0.10 \\
(1.3 \% / \\
0.4 \%)\end{array}$ & $\begin{array}{c}3.66 \\
(51.3 \% / \\
14.2 \%)\end{array}$ & $\begin{array}{c}0.10 \\
(1.3 \% / \\
0.4 \%)\end{array}$ & $\begin{array}{c}3.66 \\
(51.3 \% / \\
15.5 \%)\end{array}$ & $\begin{array}{c}3.89 \\
(54.5 \% / \\
16.4 \%)\end{array}$ \\
\hline
\end{tabular}




\subsection{Glass Sector Emission Savings}

Table 7 presents the emissions saving potential of each recovery scenario, where each recovery scenario is representative of a specified distribution of primary output into secondary application (see Figure 4 and Table 4).

The total annual emission savings for each recovery scenario were calculated with reference to the baseline annual tonnage inflows of glass products listed in Table 5 . The aspirational yield scenario yields a $2.7 \%$ reduction in total annual emissions compared to the conservative yield scenario. Thus the equivalent emission savings presented in Table 7 have been calculated with reference to (i) the conservative yield baseline for FG production (ii) the aspirational yield baseline for FG production.

Table 7: Equivalent emissions saving potential of alternative recovery scenarios based on estimated annual outflow of flat glass

\begin{tabular}{|c|c|c|c|c|c|c|c|c|c|c|c|}
\hline & & \multicolumn{4}{|c|}{ Conservative Yield (A) } & \multicolumn{6}{|c|}{ Aspirational Yield (B) } \\
\hline & & \multicolumn{2}{|c|}{ Scenario $1 A$} & \multicolumn{2}{|c|}{ Scenario $2 A$} & \multicolumn{2}{|c|}{ Scenario $1 B$} & \multicolumn{2}{|c|}{ Scenario $2 B$} & \multicolumn{2}{|c|}{ Scenario $3 B$} \\
\hline \multicolumn{2}{|c|}{$\begin{array}{l}\text { Estimate annual outflow } \\
\text { of flat glass (kt) }\end{array}$} & 200 & 600 & 200 & 600 & 200 & 600 & 200 & 600 & 200 & 600 \\
\hline \multirow{2}{*}{$\begin{array}{l}\text { Equivalent } \\
\text { emission } \\
\text { savings as } \\
\% \text { of glass } \\
\text { sector total }\end{array}$} & $\begin{array}{l}\text { (i) FG yield } \\
\text { A baseline }\end{array}$ & $0.36 \%$ & $1.09 \%$ & $1.80 \%$ & $5.39 \%$ & $0.36 \%$ & $1.09 \%$ & $1.80 \%$ & $5.39 \%$ & $1.88 \%$ & $5.63 \%$ \\
\hline & $\begin{array}{l}\text { (ii) FG yield } \\
\text { B baseline }\end{array}$ & $0.37 \%$ & $1.11 \%$ & $1.84 \%$ & $5.52 \%$ & $0.37 \%$ & $1.11 \%$ & $1.84 \%$ & $5.52 \%$ & $1.92 \%$ & $5.77 \%$ \\
\hline \multirow{2}{*}{$\begin{array}{l}\text { Equivalent } \\
\text { emission } \\
\text { savings as } \\
\% \text { of flat } \\
\text { glass } \\
\text { sector total }\end{array}$} & $\begin{array}{l}\text { (i) FG yield } \\
\text { A baseline }\end{array}$ & $1.11 \%$ & $3.33 \%$ & $5.51 \%$ & $16.52 \%$ & $1.11 \%$ & $3.33 \%$ & $5.51 \%$ & $16.52 \%$ & $5.75 \%$ & $17.26 \%$ \\
\hline & $\begin{array}{l}\text { (ii) FG yield } \\
\text { B baseline }\end{array}$ & $1.19 \%$ & $3.58 \%$ & $5.93 \%$ & $17.80 \%$ & $1.19 \%$ & $3.58 \%$ & $5.93 \%$ & $17.80 \%$ & $6.20 \%$ & $18.59 \%$ \\
\hline
\end{tabular}

\section{Discussion}

\subsection{Existing END-OF-LIFE Routes}

The flow of resources presented in Figure 2 provides a clear visualisation of the extent to which each glass market takes advantage of the use of recycled cullet in the relevant glass production processes. Several external factors have led to a significant increase in the percentages of post-consumer cullet used in new CG production in the last 25 years. The introduction of an extended producer responsibility (EPR) scheme in 1997 mobilised significant investment into effective mechanisms for the collection of container glass including kerbside and bottle bank collection. Through these schemes, $76.5 \%$ of container glass is now collected for recycling in the UK (British Glass, 2020). Technological advancements in material recovery facilities have enabled the effective sorting of mixed household waste to obtain glass cullet which can subsequently be reprocessed to an acceptable quality for the CG market. The CG market thus makes use of approximately 55\% post-consumer cullet in new production, which sits within the average for European glass manufacturers (FEVE, 2018). Consequentially, there is reduced demand for primary material resources, which in the instance of CG can contribute up to $28 \%$ of energy input - see Table 4 . 
However, there is a significant imbalance between the types of CG produced and types of glass consumed and subsequently collected in the UK (Edgar et al., 2008; Lee et al., 2019). The UK production of clear CG is more than double that of green or amber container glass (Edgar et al., 2008; WRAP, 2008a; WSP Parson Brinkerhoff and GL, 2015). Collected cullet from green or amber collection cannot be reintroduced into the production of clear container glass and is often exported to external markets (Beerkens et al., 2011; JRC European Comission, 2011).

The flat glass market accounted for $\sim 22 \%$ of UK glass production in 2019 . Figure 2 highlights the existing recovery pathways for glass products at their end-of-life. Estimates from reprocessors in the UK suggest that approximately 80 - $100 \mathrm{kt}$ of flat glass is collected per year for recycling. Despite its recyclability, end-of-life building glass is rarely recycled into new flat glass products. As an alternative, collected and sorted post-consumer flat glass is reprocessed and returned to the container glass market, where there is less stringent acceptability criteria than in the flat glass market (JRC European Comission, 2011). Once collected and sorted, both flat and container glass are typically transferred to a glass reprocessor. Private communications with glass reprocessors in the UK and the Netherlands exposed the existing capability to readily reprocess post-consumer flat glass to the container glass and glass wool markets (URM Ltd. Reprocessors, telephone communication, 29 November 2021; Maltha Glasrecycling Nederland BV, email communication, 31 December 2021). Flat glass that is unsorted from other building materials at the site of use is down-cycled by crushing it together with other building materials to use in aggregate production or as hard core for use on site, or sent to landfill disposal. Landfill disposal is feasible due to the inert properties of glass: glass qualifies for the lower rate of UK landfill tax (£3.15/tonne instead of $£ 98.60 /$ tonne). Therefore the costs for disposing flat glass are often cheaper than the cost of separately collecting and treating it to make it suitable for recycling.

Demand for glass fibres for glass wool production has increased over the last 20 years. This is largely due to the higher demand for insulation products to meet building energy performance targets. Glass wool production typically incorporates up to $55 \%$ of pre- and post-consumer cullet in new production. Cullet for use in glass wool production must also meet stringent acceptability criteria, albeit less stringent than the flat glass market (JRC European Comission, 2011). Thus, a large proportion of the cullet used in glass wool production is internal cullet and reprocessed pre-consumer cullet from the flat glass sector (Knauf Insulation, 2021).

\subsection{Energy Balance \& Emission Saving Potential}

\subsubsection{The effect of yield losses}

Cullet arising from yield losses in the several stages of glass production are incorporated into new glass production as internal and/or pre-consumer cullet. These yield losses are either returned directly to the glass melting stage or, 
as in the case for a small margin of offcuts from the flat glass manufacturing process, they are first reprocessed before returning to the flat glass or glass wool market.

A useful insight gained from Figure 2 and Table 5 is that for the same unit of final output, the use of pre-consumer cullet in new production does not alter the demand for primary raw materials from natural resources. In fact, it increases the total energy and emissions per unit of output, where the unit of output is a product that fulfils a primary application. The alternative yields presented as conservative $(A)$ and aspirational $(B)$ in Table 6 provide evidence for this. Based on the conservative yield scenario $(\mathrm{A})$, the production of $1 \mathrm{~kg}$ of flat glass output (within glazing and automotive applications) equates to an energy consumption of $25.9 \mathrm{MJ} / \mathrm{kg}$ output and $1.76 \mathrm{kgCO}$-eq / kgoutput, which is $9.2 \%$ and $8.0 \%$ higher, respectively, than the aspirational yield scenario $(\mathrm{B})$ where the same distribution of glass products with higher yields (i.e. lower levels of manufacturing waste generation) are considered. This margin may increase further if the energy costs associated with the return transportation of pre-consumer cullet to glass manufacturers are considered.

The sensitivity of energy savings to changes in yield highlights the importance of considering potential yield losses when evaluating the benefits of utilising greater proportions of post-consumer recycled glass (Beerkens et al., 2011). If higher proportions of post-consumer cullet lead to reduced yield, the associated energy savings may be diminished. Yield rates should continue to be optimised with the aim to reduce energy input across the glass value chain.

\subsubsection{Use of post-consumer flat glass cullet in secondary applications}

The use of cullet in new production has long been recognised as advantageous in terms of reduced energy input and corresponding process and combustion emissions. The existing collection infrastructure for flat glass is underestablished, meaning that these benefits are often under-exploited: a large proportion of flat glass ends up as aggregate or in landfill. The energy balance associated with the existing typical recovery route for flat glass was demonstrated through scenario $1 \mathrm{~A}$ (see Figure 3 and Table 6 for secondary application distribution). It was found that $0.4 \%$ of the energy used in new production is recovered through the reutilisation of waste glass in scenario $1 \mathrm{~A}$, where $74 \%$ of collected glass ends up as aggregate product.

The energy associated with transporting and reprocessing collected glass cullet was found to be non-negligible. The results presented in Table 6 and Table 7 are based on a total energy input of $2.66 \mathrm{MJ} / \mathrm{kg}$ reproc-cullet and $0.17 \mathrm{~kg}$

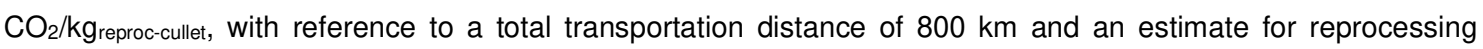
methods to provide cullet of a suitable quality for FG, GW or CG based on (Beerkens et al., 2011; Denison, 1996; GOV.UK, 2021). These figures remains less than the energy and emissions associated with the sourcing and transportation of primary raw materials which was found to be $4.05 \mathrm{MJ} / \mathrm{kg}$ and $0.316 \mathrm{~kg} \mathrm{CO}$-eq/kg, respectively, where the production of soda-ash is found to be the main contributor. 
Scenario $2 \mathrm{~A}$ provides an example of the associated benefits of improved collection practices that enable a higher percentage of flat glass to be reprocessed into cullet suitable for other glass markets. Through improved collection and distribution to high-value glass markets, the percentage of available recoverable energy increases from $0.4 \%$ (S1A - 11\% collected glass reprocessed to furnace-ready cullet) to $14.2 \%$ (S2A - $90 \%$ of collected glass reprocessed to furnace-ready cullet). This figure is comparable with the available literature. For example, one study evaluated the energy implications of glass container recycling in the US including transportation distances and calculated that the total primary energy use decreases as the percent of glass recycled rises by a maximum saving of $13 \%$ (Gaines et al., 1994). Alternative methods of transportation and transportation distances for collected glass will remain a key factor to monitor in order to assess the sensitivities in the calculated energy and emission savings. Further research on the locations of reprocessing facilities, collection sites and glass manufacturing facilities in the UK, and their relevant production capabilities would be valuable.

Scenarios $2 \mathrm{~A}$ and $2 \mathrm{~B}$ consider end-of-life recovery routes that differ from scenarios $1 \mathrm{~A}$ and $1 \mathrm{~B}$. In scenarios $2 \mathrm{~A}$ and $2 \mathrm{~B}, 30 \%$ of collected flat glass is siphoned to the CG market. The remainder is distributed to FG, GW and AGG at $30 \%, 30 \%$ and $10 \%$, respectively. Scenario $3 \mathrm{~B}$ considers a situation where $90 \%$ of collected cullet is siphoned to $\mathrm{FG}$ and $10 \%$ to $\mathrm{AGG}$. Scenarios $2 \mathrm{~B}$ and $3 \mathrm{~B}$ translate to a recovered energy percentage of $15.5 \%$ and $16.4 \%$, respectively. The marginal difference highlights that the use of collected FG in alternative markets where there are less stringent requirements for cullet quality could still significantly contribute to reducing the energy demand of the glass sector as a whole.

The flat glass market is projected to grow as a result of the continued drive to refurbish existing builds in order to meet new energy performance targets: it is projected that $44 \%$ of the existing glass stock in the EU is single-glazed (Glass for Europe, 2018). Figure 2 provides a representative example of existing collection practices for flat glass based on an estimated outflow of $485 \mathrm{kt}$. This estimate was considered reasonable, based on the 1996 flat glass production figure of $690 \mathrm{kt}$ in the UK (Kellenberger et al., 2007; Maria et al., 2013) and given that the typical expected lifetime of an insulated glazing unit (IGU) is 25-30 years. (Kellenberger et al., 2007) estimated that IGUs account for between $40-50 \%$ of the architectural glazing market by mass. The estimated outflow of $485 \mathrm{kt}$ shown on Figure 2 thus also aligns to some extent with the prediction of $215 \mathrm{kt}$ outflow in 2025 evaluated by (Hestin et al., 2016) where they used a top-down method to estimate glass stock based on the typical mass of insulated glazing units (IGUs) alone, i.e. where this could be considered as $40-50 \%$ of the total architectural glass market. In Table 7, two alternative estimates were considered for the outflow of flat glass stock per annum, based on the production figures for flat glass in 1996 and energy- and emission-saving potential for the various scenarios constructed in this study. The low-end estimate outflow at $200 \mathrm{kt}$, would yield $1.8 \%$ savings in $\mathrm{CO}_{2}$ emissions across the glass sector and $5.5 \%$ savings in the flat glass sector alone for scenario $2 \mathrm{~A}$. For the same scenario, the high-end outflow estimate of $600 \mathrm{kt}$ would yield $5.4 \%$ savings in emissions across the glass sector and $16.5 \%$ within the flat glass 
sector alone. Moving towards more aspirational manufacturing yield (B) could reduce emissions by a further 1-2\%. Inflows and outflows of glass products arising from imports and exports that have not been included in this study. EU-27 imports and exports have been found to account for $10-20 \%$ of UK flat glass production and consumption. Bottom-up research of the existing glass stock is necessary to formalise projections of glass outflows.

\subsection{Barriers to the Use of Post-Consumer Cullet}

Fears surrounding incorporating post-consumer cullet in flat glass production have arisen from concerns over contamination from glass-ceramics, organic materials and metals. The incorporation of unknown and uncontrolled compositions of cullet can result in high production losses and set back flat glass production for several days. These problems can include: glass melting disturbances by foaming or limited heat transfer into melt caused by a changed carbon content of incoming cullet via polymers; the build-up of ceramic inclusions that have a very low dissolution rate in the glass melt; the build-up of nickel-sulphide inclusions formed due to contamination of the glass melt by stainless steel flakes; reduction of silica into silicon inclusions due to the reducing effect of aluminium contaminants; and/or downward drilling of melts of metals present in the cullet (Beerkens et al., 2011; IMPEL, 2012). Such problems can lead to refining difficulties; reduced furnace lifetime; product colour changes; reduced mechanical strength due to differing thermal expansion coefficients between the glass and inclusions; fumes from organic contamination; and emissions of particulate matter arising mainly from the volatilisation and subsequent condensation of volatile batch materials (Maria et al., 2013). The effects of polymer contaminants on the altered carbon content of the glass melt can be mitigated to some extent by adding sodium or potassium nitrate as an oxidising agent to stablise the redox state of the glass (Beerkens, 1999; Maria et al., 2013; Zier et al., 2021). However, this will consequently increase the nitrogen oxide (NOx) emissions (Maria et al., 2013).

To prevent these problems, preliminary purification and sorting of post-consumer cullet is normally required (Maria et al., 2013; Zier et al., 2021). This can involve a series of reprocessing steps: waste glass is passed through a series of separation techniques including magnets, screens, cyclones, eddy current separators, cameras and Xray equipment, in order to sort and grade the quality of reprocessed cullet. The necessary reprocessing methods and resultant cullet quality can vary significantly and is highly dependent on which secondary processes have been utilised and the condition upon collection. For example, cleanly collected tempered glass free from interface materials can be readily reprocessed and recycled to 'furnace-ready' cullet. Alternatively, ceramic-fritted glass is difficult to recycle due to the high melting temperature of ceramics leading to ceramic inclusions in the final glass product. Concerns over re-introducing laminated glass directly into the float glass tank have arisen from the organic poly-vinyl butyral interlayer - which can account for $7 \%$ by weight of the laminated glass sheet - altering the finely controlled redox state of the glass (Beerkens, 1999; Beerkens et al., 2011). Thus, laminated glass necessitates more specialised reprocessing techniques to separate the glass from the polymer interlayer prior to use. This 
usually involves breaking up the glass using a roller or similar mechanical action, followed by removal of the glass (Fernández Acevedo et al., 2008; Tupy et al., 2014). Each additional reprocessing step may lead to additional costs and yield losses. Some FG manufacturers have more recently developed partnerships with local insulated glazing unit installers to recover post-consumer FG to use as cullet in new FG production (Morley Glass \& Glazing, 2019; Saint Gobain, 2020). Options for alternative secondary applications include foam glass, glass abrasives and glass beads, where there are less stringent quality requirements (Brusatin et al., 2004; JRC European Comission, 2011; Kasper, 2006; Lebullenger and Mear, 2019). However, these applications have been found to yield significantly less environmental savings than higher-value glass applications (Enviros Consulting Ltd, 2003; Hartwell and Overend, 2019).

An improved understanding of the ability to enhance collection and reprocessing of post-consumer glass to the key glass markets is essential. Whilst existing levels of post-consumer cullet remain relatively low across all glass markets, it would be beneficial to consider grading post-consumer flat glass cullet to then distribute to relevant markets based on quality. The reprocessing yield associated with generating 'furnace-ready' cullet from different flat glass product types will require further research. Meanwhile, technical methods that help to increase the efficiency of sorting and reprocessing flat glass products that contain adhering polymers/sealants would help to increase the yield rates of reprocessing and maximise the quality of returned cullet. A consistent and reliable supply of reprocessed cullet of an acceptable quality will be essential to mitigate the risk associated with incorporating contaminants in new glass production, and subsequently aid the transition to incorporating higher percentages of post-consumer glass. It is clear from the difference in the total energy required per unit of output in conservative (25.9 MJ/kgoutput) and aspirational (23.7 MJ/kgoutput) yield scenarios evidenced in Table 6 , that an increase in postconsumer cullet must not come at the expense of increased yield losses.

Aside from environmental opportunities, financial opportunities stimulated through market-mechanisms and/or external legislation, will remain the key driver to the adoption of post-consumer waste glass recycling. Two key factors need to be evaluated to realise the market opportunities for post-consumer flat glass cullet and ensure competitiveness with primary raw materials. Firstly, the cost of collection, reprocessing and transportation will have to be assessed alongside the negated costs for the equivalent quantity of raw materials. Several reprocessing sites exist in the UK and nearby countries. The added costs associated with collection and transportation to relevant sites requires further investigation. The second crucial factor to demonstrate economic feasibility is the direct and indirect financial savings that arise from production of glass products that use of higher proportions of postconsumer cullet. Energy costs represent a large proportion of operating expenditure in UK energy-intensive industries (Griffin et al., 2016). The use of post-consumer cullet of an acceptable quality, will reduce direct energy costs due to lowered furnace operating temperatures. Similarly, negated emissions through the use of postconsumer cullet have the potential to reduce indirect costs incurred to glass manufacturers via the UK emissions 
trading scheme (ETS). The financial consequences of energy and emission savings require further research. This could help to direct UK policy on ETS, carbon taxes and necessary subsidies/loans that support the necessary take-back infrastructure (Norman, 2013).

In the instance where market opportunities for cullet have not been realised, revisions to external legislation (voluntary and involuntary) will be necessary. VlakGlas Organisation in the Netherlands facilitates an extended producer responsibility (EPR) scheme for flat glass products (Vlakglas, 2021). Insulated glazing unit fabricators pay a levy on finished products which supports the provision of a network of collection sites and supporting logistics. The UK container glass implemented the Producer Responsibility Obligations (Packaging Waste) Regulations legislation in 1997 to align with the EU Packaging Waste Directive released in 1994. The regulations place responsibilities on the producers and handlers of packaging to achieve periodically updated recycling targets. The high recycling rates in the container glass industry are, in part, a reflection of the success of this scheme. The effectiveness of these schemes in the context of the UK flat glass sector requires further research. Additional legislation for the handling of glass waste at the end-of-life stage also requires attention. Glass for Europe takes the view that the current targets on building waste materials presented in the EU Waste Framework directive do not provide enough incentive to recycle glass because glass represents less than 5\% of the C\&D waste (European Parliament and Council, 2008; Glass for Europe, 2018). They suggest material-specific targets for waste and/or the introduction of mandatory provisions to dismantle and sort building glass. UK-based BREEAM certification schemes call for $95 \%$ of construction materials to be reutilised in some form. There is currently no specification for the type of reuse, therefore the use of flat glass in aggregate products would receive the same credit as the use in higher value products. Future revisions to legislation and/or accreditation schemes such as BREEAM would help to share the responsibility of high-value recycling across the glass value-chain. Such an approach would necessitate audits at the demolition or refurbishment stage to detail the type and dimensions of glass products for example, laminated or tempered. This process could be automated in the future through the implementation of material passports in BIM models and/or RFID tracking, to provide details of the glass composition, processing methods and reuse/recycling potential (Honic et al., 2021; Luscuere et al., 2019; Rose and Stegemann, 2018).

The aggregates levy is a UK tax on the exploitation of primary raw materials. Inadvertently, this creates a demandside pull for crushed flat glass from the aggregate market. Glass also qualifies for the lower grade of landfill tax due to its inert properties. Improved awareness of the environmental and economic costs of the existing recovery pathways for flat glass to these low-value applications is required, to provide supporting information to revisions in policy. Policy must be carefully considered in such a way that does not reduce domestic competitiveness or promote international trade in regions with less energy-efficient manufacturing processes (Peters et al., 2011). 


\subsection{Alternative Routes to Minimise Energy InPut}

The annual emission savings for scenario 3B featured in Table 7 show that even in the event that $90 \%$ of flat glass is collected from a yearly outflow of $600 \mathrm{kt}$, the emissions associated with yearly production (950 kt) could be reduced by a maximum of $18.6 \%$. Beyond the use of post-consumer cullet, energy consumption will be depend on the: energy source; type of furnace/heating technique; heat recovery method for primary processing; and choice of secondary processing methods.

Existing studies have reviewed the energy consumption and decarbonisation options available through furnace type and alternative fuel sources, including: oxy-fuel melting, biofuels, hydrogen, all electric-melting, and hybrid furnaces (Griffin et al., 2021; Ireson et al., 2019; Maria et al., 2013; Zier et al., 2021). Furnace type, age, capacity and throughput have been found to significantly affect the energy efficiency of the glass furnace (Glass Technology Services Ltd, 2004; Maria et al., 2013; Zier et al., 2021). Alternative fuel sources have the ability to reduce on-site energy consumption for glass production. However, they must be carefully considered in terms of availability, electricity required to generate them (scope $2-3$ emissions) and other environmental costs/benefits. A fuel source that saves energy on site, but indirectly leads to greater upstream emissions, may not be a favourable choice. For example, electricity is used for the purification of oxygen to be used as a fuel source. It has been suggested that the $\mathrm{CO}_{2}$ saving from the use of oxy-fuel furnaces are generally low when upstream emissions are considered (Ireson et al., 2019), however, the strongly reduced NOx emissions are worth noting (Zier et al., 2021). Better consideration of indirect $\mathrm{CO}_{2}$ emissions are of particular importance in the global industry sector where scope 2 and 3 emissions have been found to have nearly doubled between 1995-2015 (Hertwich and Wood, 2018)

Based on the existing distribution of flat glass products, the energy losses arising from the primary and secondary processing methods of $1 \mathrm{~kg}$ of flat glass production are around $60 \%$ of total energy input. Primary energy losses have the ability to be recovered through heat recovery methods (Maria et al., 2013; Norman, 2013; Zier et al., 2021). (British Glass, 2021) highlight that the majority of glass furnaces in the UK have regenerators that recover some waste heat which is used to pre-heat the combustion air. However, about a third of energy input to a gas fired furnace exits as waste heat in the flue gases. This waste heat could be utilised to pre-heat the raw materials using a batch and/or cullet preheater, as a result improving the efficiency of the melting process (British Glass, 2021).

Secondary processing methods were found to contribute up to $23 \%$ of the original energy input based on the typical distribution of flat glass products (see Table 6) evaluated in this study. This is largely due to the toughening and laminating processes. The production of poly-vinyl butyral is a significant factor in the relatively high energy costs for lamination. Thus, options for the use of thinner interlayers or alternative materials should be investigated. Toughened glass involves unavoidable high temperatures for processing. However, increased awareness of the 
environmental cost of specifying secondary processing methods would help to ensure that design options are optimised to provide sufficient function at minimum energy input.

Alternative options for material efficiency such as the direct reuse of flat glass, would avoid the need for remelting cullet and energy-intensive secondary processing methods, which could result in higher energy savings. However, as demonstrated by (Afolabi et al., 2016; Datsiou and Overend, 2017), strength-reducing flaws accumulate on exposed glass surfaces of glass during its service life. Therefore the suitability of reuse as a viable recovery option, requires further research on the trade-offs in performance and possible reconditioning methods.

\subsection{LIMITATIONS OF DATA AND SCOPE}

For the purpose of this study, some assumptions have been made that will affect the energy and emissions savings presented. Where UK energy data was unavailable, the data used to calculate the reference energy input and $\mathrm{CO}_{2}-$ eq emissions per annum for each glass sector is based on average dataset for furnace technology in the EU in 2005-2007 (Schmitz et al., 2011). The furnaces available within the glass industry, and within each sub-sector, vary considerably in size, throughput, melting technique, design, age, raw materials utilised, and the abatement techniques applied. For example, a more inefficient furnace could yield higher energy savings. Therefore, the absolute values for recovered energy and emissions calculated in this study should not be considered exhaustive.

The use of cullet was taken to reduce energy consumption by $3 \%$ for every $10 \%$ increase of cullet based on (Beerkens et al., 2011). In reality this figure may vary: (Glass Technology Services Ltd, 2004) evaluated the use of cullet in container furnaces and found a variation of energy savings between $2-4 \%$ for every $10 \%$ increase in cullet, depending on furnace size, age, moisture content and total percentage of cullet.

This study provides information on the influence of secondary-processes on the embodied and end-of-life stages of the flat glass product lifecycle. To obtain a more holistic view on the trade-offs in energy inputs with final product application and reuse, it will be necessary to consider other life-cycle stages such as operation and use which can significantly reduce the use of energy in buildings (Maria et al., 2013; O'neill et al., 2020; Rayment, 1989).

\section{CONCLUSION}

In order to initiate public and/or private investment to promote effective collection and reprocessing schemes, it is critical to have a better understanding of the existing environmental opportunities of increased cullet usage across the glass value-chain. This study set out to map the UK glass supply-chain from nature resource through to endof-life recovery and disposal. Based on this, it further sought to understand the environmental cost of production and evaluate the feasibility of improved collection and recycling rates of flat glass as a route to reduce the GHG 
emissions from the UK glass sector. Subsequently, the main legislative, technological, supply-chain and economic influences for the wide variance in the use of cullet in place of primary raw materials between glass sub-sectors were critically reviewed.

A clear distinction between internal/pre-consumer cullet and post-consumer cullet is necessary when considering the recycled content of a unit of flat glass output. The use of post-consumer cullet is the sole factor that has the potential to deliver energy savings in new flat glass production. Whilst the use of internal or pre-consumer cullet reduces the quantity of manufacturing waste to landfill, the analysis of alternative production yield rates (conservative and aspirational) provides evidence that the production of internal / pre-consumer waste increases the total energy input required per unit output of finished glass product (see Table 6). The additional energy input attributed to the production of internal and pre-consumer waste, i.e. glass that does not spend a period of time in use, should thus be included in the reporting for the total energy per unit output of finished glass product.

The use of post-consumer cullet in new glass production is the only existing option that is technologically readily available to reduce process emissions. Other options for reducing process emissions such as the use of alternative raw materials or carbon dioxide removal (CDR) technologies are in their early stages of development. Container glass manufacturers use relatively high percentages of post-consumer cullet in new production, as a consequence of long-established extended producer responsibility schemes and supporting collection infrastructure and sorting processes. The collection of flat glass products for recycling at their end-of-life is estimated to be at a rate of $10 \%$ of new flat glass production. With the exception of a few small-scale initiatives, collected flat glass is rarely returned to the flat glass market. Thus glass manufacturers typically operate at $<1 \%$ post-consumer cullet. One of the key limitations of incorporating higher percentages of post-consumer flat glass incorporating post-consumer in new production is the stringent acceptability criteria for cullet which exists to prevent yield losses. Given the known imbalance in the types of CG produced and consumed in the UK, the outcomes of this study highlight that the option for collected flat glass to be incorporated into container glass products could yield significant energy savings supported by market demand. In this study, it was found that emission savings of $5.4 \%$ (30\% to FG, $30 \%$ to GW, $30 \%$ to $C G, 10 \%$ to $A G G)$ and $5.6 \%(90 \%$ to $F G, 10 \%$ to $A G G)$ can be found across the whole glass sector through improved flat glass recovery alone. These figures are based on a high-end estimate output of $600 \mathrm{kt}$ collected flat glass. It draws attention to the fact that significant energy and emission savings can be made through the reutilisation of cullet in CG and GW applications, in the instances where the acceptability criteria for flat glass cannot be met. Alternative mechanisms for collection that sort flat glass cullet more effectively should be investigated. It would be beneficial to track the recovered cullet from collection site through to reprocessor to understand what quality is achievable and thus promote efficient collection methods.

Access to flat glass cullet in the UK is currently limited: an improved understanding of the existing market opportunity to advance improvements in existing deconstruction and collection practices is required. This study 
identified the key financial elements that will influence the transition from the use of primary raw materials to higher percentages of post-consumer cullet. These include, but are not limited to: added costs for cullet transportation, reprocessing and storage; savings in primary raw material costs; savings in the $\mathrm{CO}_{2}-$ emission related taxes due to reduced production emissions; and savings in landfill taxes. Further research should look to develop an economic model that considers these factors collectively, to attract relevant investment and/or provide evidence for supporting policy where necessary. Any additional costs to glass manufacturers will need to be distributed across the valuechain to ensure that the UK remains competitive and avoid imports from less energy-efficient manufacturing.

The existing production process for glass inherently necessitates the use of energy to melt constituent raw materials including cullet. Thus, further reductions in emissions beyond recycling will undoubtedly call for a transition to lowcarbon energy sources and new furnace technologies. The work of Glass Futures UK looks to expand the capacity of these fuel sources. UK demand for renewable energy sources will continue to rise as the UK seeks to decarbonise all sectors. Thus all options for energy efficiency improvements will need to be considered holistically. By focusing decarbonization options centred on the energy input and GHG emissions associated with glass production alone (scope 1 emissions), a direct reduction may be offset by an increase in other areas of the valuechain such as fuel supply or raw material sourcing. This 'carbon leakage' effect may involve an overall rise in global emissions. For this reason, this study includes raw material sourcing and processing and energy input and emissions associated with fuel supply to reduce the burden of searching for alternative energy sources. Other valuable approaches for reducing energy input will need to: better understand the feasibility ways of facilitating flat glass reuse since this eliminates the need for remelting; optimise procurement routes for primary raw materials e.g. sourcing, processing and transportation; and promote secondary processing methods that provide sufficient functional performance at minimal environmental cost.

\section{CREDIT AUTHORSHIP CONTRIBUTION STATEMENT}

Rebecca Hartwell: Conceptualization, Methodology, Material preparation, Investigation, Data collection and formal analysis, Visualization, Writing - original draft, Writing - review \& editing, Project administration. Graham

Coult: Conceptualization, Methodology, Writing - review \& editing. Mauro Overend: Conceptualization, Supervision, Writing - review \& editing.

\section{DECLARATION OF COMPETING INTEREST}

The authors declare that they have no known competing financial interests or personal relationships that could have appeared to influence the work reported in this paper. 


\section{ACKNOWLEDGEMENTS}

This work was supported by the UK Engineering and Physical Sciences Research Council (EPSRC) for the University of Cambridge Centre for Doctoral Training in Future Infrastructure and Built Environment (EPSRC grant reference number EP/L016095/1). The authors would like to extend their thanks to Dr. José Cruz Azevedo for sharing his experience in mapping material resource flows in the early developmental stages of this research. 


\section{References}

Action, T.H.E., For, P., Uk, T.H.E., 2020. Close the glass loop: The action plan for the UK.

Afolabi, B., Norville, H.S., Morse, S.M., 2016. Experimental Study of Weathered Tempered Glass Plates from the Northeastern United States. J. Archit. Eng. 22. https://doi.org/10.1061/(asce)ae.1943-5568.0000220

Allwood, J.M., Ashby, M.F., Gutowski, T.G., Worrell, E., 2013. Material efficiency: Providing material services with less material production. Philos. Trans. R. Soc. A Math. Phys. Eng. Sci. 371. https://doi.org/10.1098/rsta.2012.0496

Anderson, K., Peters, G., 2016. The trouble with negative emissions. Science (80-. ). https://doi.org/10.1126/science.aah4567

Barrett, J., Pye, S., Betts-Davies, S., Eyre, N., Broad, O., Price, J., Norman, J., Anable, J., Bennet, G., Brand, C., Carr-Whitworth, R., Marsden, G., Oreszczyn, T., Giesekam, J., Garvey, A., Ruyssevelt, P., Scott, K., 2021. The role of energy demand reduction in achieving net-zero in the UK.

Beerkens, R., 1999. Redox and sulphur reactions in glass melting processes. Ceram. - Silikaty 43, $123-131$.

Beerkens, R., Kers, G., Van Santen, E., 2011. Recycling of post-consumer glass: Energy savings, CO2 emission reduction, effects on glass quality and glass melting, in: Ceramic Engineering and Science Proceedings. https://doi.org/10.1002/9781118095348.ch16

BEIS, 2020. 2020 Government greenhouse gas conversion factors for company reporting: Methodology paper for conversion factors.

BEIS, British Glass, 2017. Glass Sector Joint Industry-Government Industrial Decarbonisation and Energy Efficiency Roadmap Action Plan.

Belis, D., Tuokko, K., 2016. Sectoral case study - Soda ash.

British Glass, 2021. Glass sector Net zero strategy 2050.

British Glass, 2020. Environment Bill: British Glass (EB80).

Brunner Mond, 2008. House of Lords - European Union - Written Evidence - Memorandom by Brunner Mond.

Brusatin, G., Bernardo, E., Scarinci, G., 2004. Production of foam glass from glass waste, in: Proceedings of the International Conference on Sustainable Waste Management and Recycling: Glass Waste.

Butnar, I., Cronin, J., Pye, S., 2020. Review of Carbon Capture Utilisation and Carbon Capture and Storage in future EU decarbonisation scenarios, Carbon Capture and Storage Association.

Centre for Low Carbon Futures, 2011. Technology Innovation for Energy Intensive Industry in the United Kingdom.

Cullen, J.M., Allwood, J.M., 2013. Mapping the global flow of aluminum: From liquid aluminum to end-use goods. Environ. Sci. Technol. 47. https://doi.org/10.1021/es304256s

Cullen, J.M., Allwood, J.M., Bambach, M.D., 2012. Mapping the global flow of steel: From steelmaking to end-use goods. Environ. Sci. Technol. 46, 13048-13055. https://doi.org/10.1021/es302433p

Datsiou, K.C., Overend, M., 2017. The strength of aged glass. Glas. Struct. Eng. 2, 105-120. https://doi.org/10.1007/s40940-017-0045-6

DeBrincat, G., Babic, E., 2018. Re-thinking the life-cycle of architectural glass. Ove Arup Partners.

Denison, R.A., 1996. Environmental Life-Cycle Comparisons of Recycling, Landfilling and Incineration: A Review of Recent Studies. Annu. Rev. Energy Env. 21, 191-237.

Edgar, R., Holcroft, C., Pudner, M., Hardcastle, G., 2008. UK Glass manufacture: A Mass Balance Study.

Enviros Consulting Ltd, 2003. Glass Recycling - Life Cycle Carbon Dioxide Emissions. Sheffield.

European Parliament and Council, 2008. Directive 2008/98/EC of the European Parliament and of the Council of 19 November 2008 on waste and repealing certain directives. Off. J. Eur. Union 3-30. https://doi.org/2008/98/EC.; 32008L0098

Fernández Acevedo, C., Martínez De Morentín Osaba, L., Osés Arteta, E., Medina Herrera, G., Fernández 
Fernández, María, A., 2008. Polyvinyl Butyral Recycling Method. EP 2308919 B1.

FEVE, 2018. Latest Glass Packaging Recycling Rate Steady at 76\% [WWW Document]. URL https://feve.org/glass_recycling_stats_2018/(accessed 12.3.21).

Gaines, L.L., Mintz, M.M., Shepherd, P.B., 1994. Energy Implications of Glass-Container Recycling. https://doi.org/10.12968/sece.2008.6.1230

GHG Protocol Initiative, 2012. A Corporate Accounting and Reporting Standard, The Greenhouse Gas Protocol.

Glass for Europe, 2018. Europe's flat glass industry in a competitive low carbon economy.

Glass Technology Services Ltd, 2004. A Study of the Balance between Furnace Operating Parameters and Recycled Glass in Glass Melting Furnaces.

GOV.UK, 2021. Greenhouse gas reporting: conversion factors 2021 - GOV.UK [WWW Document]. URL $\mathrm{https://www.gov.uk/government/publications/greenhouse-gas-reporting-conversion-factors-2021} \mathrm{(accessed}$ 12.12.21).

Griffin, P.W., Hammond, G.P., McKenna, R.C., 2021. Industrial energy use and decarbonisation in the glass sector: A UK perspective. Adv. Appl. Energy 3, 100037. https://doi.org/10.1016/j.adapen.2021.100037

Griffin, P.W., Hammond, G.P., Norman, J.B., 2016. Industrial energy use and carbon emissions reduction: a UK perspective. Wiley Interdiscip. Rev. Energy Environ. 5, 684-714. https://doi.org/10.1002/wene.212

Guardian Europe, 2021. Flat glass: Uncoated flat glass, laminated safety glass and coated flat glass.

Guardian Europe, 2012. EPD Flat glass, toughened safety glass and laminated safety glass.

Hammond, G., Jones, C., 2011. Embodied Carbon: The Inventory of Carbon and Energy (ICE).

Hammond, G.P., Norman, J.B., 2012. Decomposition analysis of energy-related carbon emissions from UK manufacturing. Energy 41, 220-227. https://doi.org/10.1016/j.energy.2011.06.035

Hartwell, R., Macmillan, S., Overend, M., 2021. Circular economy of façades: Real-world challenges and opportunities. Resour. Conserv. Recycl. 175. https://doi.org/10.1016/j.resconrec.2021.105827

Hartwell, R., Overend, M., 2019. Unlocking the Re-use Potential of Glass Façade Systems, in: Glass Performance Days 2019. Tampere, Finland, pp. 273-280.

Hertwich, E.G., Wood, R., 2018. The growing importance of scope 3 greenhouse gas emissions from industry. Environ. Res. Lett. 13. https://doi.org/10.1088/1748-9326/aae19a

Hestin, M., De Veron, S., Burgos, S., 2016. Economic study on recycling of building glass in Europe.

HM Government, 2021. Net Zero Strategy: Build Back Greener.

Honic, M., Kovacic, I., Aschenbrenner, P., Ragossnig, A., 2021. Material Passports for the end-of-life stage of buildings: Challenges and potentials. J. Clean. Prod. 319, 128702. https://doi.org/10.1016/j.jclepro.2021.128702

IMPEL, 2012. Summary of Energy-Related Information for the Manufacture of Glass and Proposal for the Sector Specific Supplement to the Draft Applicaiton Form for Energy Efficiency.

Insulation, K., 2020. Environmental Product Declaration: Glass mineral wool insulation $0.040-0.046$ W/mK.

Ireson, R., Fuller, A., Woods, J., Simon, R., Andrews, G., Bingham, P., Hakes, S., Davies, M., 2019. Alternative Fuel Switching Technologies for the Glass Sector.

Isover, 2021. Environmental Product Declaration: Glass Wool Insulation 4 + without facing.

JRC European Comission, 2011. End-of-Waste Criteria for Glass Cullet: Technical Proposals. https://doi.org/10.2791/7150

Kasper, A., 2006. Recycling of Cullet into Flat Glass Melting Furnaces, in: Kriven, W.M. (Ed.), Ceramic Engineering and Science Proceedings. The American Ceramic Society. https://doi.org/10.1002/9780470291306.ch14

Kellenberger, D., Althaus, H., Künniger, T., Lehmann, M., Jungbluth, N., 2007. Life Cycle Inventories of Building Products.

Knauf Insulation, 2021. How we are tackling embodied carbon [WWW Document]. URL https://www.knaufinsulation.com/how-we-are-tackling-embodied-carbon (accessed 12.9.21). 
Lebullenger, R., Mear, F.O., 2019. Glass Recycling, in: Musgraves J.D., Hu J., Calvez L. (Eds.), Springer Handbook of Glass. https://doi.org/10.1007/978-3-319-93728-1_39

Lee, P., Bell, N., Garcia, T., Lee, O., Harding, J., Baker, K., 2019. Recycling DRS in Scotland.

Leong, M.S., Hurley, J., 2004. Flat glass waste in the domestic window replacement industry, in: Proceedings of the International Conference on Sustainable Waste Management and Recycling: Glass Waste. pp. 249256.

Luscuere, L., Zanatta, R., Mulhall, D., Boström, J., Elfström, L., 2019. Operational materials passports, Buildings as Material Banks (BAMB).

Maria, S.B., Marcos, G.M., Querol, S.A., Serge, R., Bianca Maria, S., MUÑOZ Marcos, G., Aivi Querol, S., Serge, R., SANCHO Luis, D., 2013. Best Available Techniques (BAT) Reference Document for the Manufacture of Glass. https://doi.org/10.2791/69502

Morley Glass \& Glazing, 2019. Morley Glass \& Glazing and Saint-Gobain Glass take recycling to the next level [WWW Document]. URL https://www.morleyglass.co.uk/morley-glass-takes-recycling-to-the-next-level/ (accessed 2.24.22).

Norman, J.B., 2013. Industrial Energy Use and Improvement Potential.

O'neill, R., Window, A., Kenway, S., Dargusch, P., 2020. Integrated operational and life-cycle modelling of energy, carbon and cost for building façades. https://doi.org/10.1016/j.jclepro.2020.125370

ONS, 2021. UK manufacturers' sales by product 2019 [WWW Document]. URL https://www.ons.gov.uk/businessindustryandtrade/manufacturingandproductionindustry/datasets/ukmanufa cturerssalesbyproductprodcom (accessed 5.19.21).

Peters, G.P., Minx, J.C., Weber, C.L., Edenhofer, O., 2011. Growth in emission transfers via international trade from 1990 to 2008. Proc. Natl. Acad. Sci. U. S. A. 108, 8903-8908. https://doi.org/10.1073/pnas.1006388108

Plotly Technologies Ltd., 2015. Collaborative data science.

Rayment, R., 1989. Energy savings from sealed double and heat reflecting glazing units. Build. Serv. Eng. Res. Technol. https://doi.org/10.1177/014362448901000304

Rose, C.M., Stegemann, J.A., 2018. Characterising existing buildings as material banks (E-BAMB) to enable component reuse. Proc. Inst. Civ. Eng. Eng. Sustain. 172, 129-140. https://doi.org/10.1680/jensu.17.00074

Saint Gobain, 2020. A guide for improved cullet recycling. Glas. Forever.

Schmitz, A., Kamiński, J., Maria Scalet, B., Soria, A., 2011. Energy consumption and CO2 emissions of the European glass industry. Energy Policy 39. https://doi.org/10.1016/j.enpol.2010.09.022

Souviron, J., Khan, A.Z., 2021. The materiality of transparency: An environmental analysis of the architectural flat glass industry since 1945 in Europe, France and Belgium. Resour. Conserv. Recycl. 174, 105779. https://doi.org/10.1016/j.resconrec.2021.105779

The Royal Society, 2021. Carbon dioxide capture and storage: A route to net zero for power and industry. Clim. Chang. Sci. Solut. 1-13.

Tupy, M., Mokrejs, P., Merinska, D., Svoboda, P., Zvonicek, J., 2014. Windshield recycling focused on effective separation of PVB sheet. J. Appl. Polym. Sci. https://doi.org/10.1002/app.39879

Usbeck, V.C., Pflieger, J., Sun, T., 2014. Life Cycle Assessment of Float Glass. https://doi.org/10.1016/B978-012-386454-3.00627-8

Valpak, 2012. PackFlow 2017.

Vitro, 2022. Vitro Architectural Glass Flat Glass Products.

Vlakglas, 2021. Vlakglasrecycling Nederland [WWW Document]. URL https://www.vlakglasrecycling.nl/ (accessed 10.25.21).

Wernet, G., Bauer, C., Steubing, B., Reinhard, J., Moreno-Ruiz, E., Weidema, B., Zah, R., Wernet wernet, G., 2016. The ecoinvent database version 3 (part I): overview and methodology. Int. J. Life Cycle Assess. 21, 1218-1230. https://doi.org/10.1007/s11367-016-1087-8

Westbroek, C.D., Bitting, J., Craglia, M., Azevedo, J.M.C., Cullen, J.M., 2021. Global material flow analysis of glass: From raw materials to end of life. J. Ind. Ecol. 25, 333-343. https://doi.org/10.1111/jiec.13112 
WRAP, 2009. Flat Glass Collection: The benefits of good practice.

WRAP, 2008a. Realising the value of recovered glass: An update.

WRAP, 2008b. Collection of flat glass for use in flat glass manufacture: A Good Practice Guide. Oxfordshire.

WRAP, 2007. Assessment of the International Trading Markets for Recycled Container Glass and their Environmental Implications.

WSP Parson Brinkerhoff, GL, D., 2015. Industrial Decarbonisation \& Energy Efficiency Roadmaps to 2050: Cross Sector Summary 31.

Zier, M., Stenzel, P., Kotzur, L., Stolten, D., 2021. A review of decarbonization options for the glass industry. Energy Convers. Manag. X 10, 100083. https://doi.org/10.1016/j.ecmx.2021.100083 


\section{Supplementary Files}

This is a list of supplementary files associated with this preprint. Click to download.

- GSEMappingFGvaluechain27022022appendix.pdf 